\title{
A novel system for large-scale storage of electricity as synthetic natural gas using reversible pressurized solid oxide cells
}

\author{
Butera, Giacomo; Jensen, Søren Højgaard; Clausen, Lasse Røngaard
}

Published in:

Energy

Link to article, DOI:

10.1016/j.energy.2018.10.079

Publication date:

2018

Document Version

Peer reviewed version

Link back to DTU Orbit

Citation (APA):

Butera, G., Jensen, S. H., \& Clausen, L. R. (2018). A novel system for large-scale storage of electricity as synthetic natural gas using reversible pressurized solid oxide cells. Energy, 166, 738-754.

https://doi.org/10.1016/j.energy.2018.10.079

\section{General rights}

Copyright and moral rights for the publications made accessible in the public portal are retained by the authors and/or other copyright owners and it is a condition of accessing publications that users recognise and abide by the legal requirements associated with these rights.

- Users may download and print one copy of any publication from the public portal for the purpose of private study or research.

- You may not further distribute the material or use it for any profit-making activity or commercial gain

- You may freely distribute the URL identifying the publication in the public portal 


\section{Accepted Manuscript}

A novel system for large-scale storage of electricity as synthetic natural gas using reversible pressurized solid oxide cells

Giacomo Butera, Søren Højgaard Jensen, Lasse Røngaard Clausen

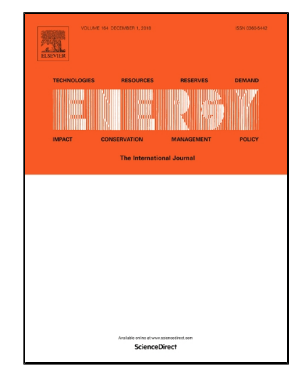

PII: $\quad$ S0360-5442(18)32069-3

DOI: $\quad 10.1016 / j$.energy.2018.10.079

Reference: $\quad$ EGY 13976

To appear in: $\quad$ Energy

Received Date: $\quad 28$ March 2018

Accepted Date: $\quad 14$ October 2018

Please cite this article as: Giacomo Butera, Søren Højgaard Jensen, Lasse Røngaard Clausen, A novel system for large-scale storage of electricity as synthetic natural gas using reversible pressurized solid oxide cells, Energy (2018), doi: 10.1016/j.energy.2018.10.079

This is a PDF file of an unedited manuscript that has been accepted for publication. As a service to our customers we are providing this early version of the manuscript. The manuscript will undergo copyediting, typesetting, and review of the resulting proof before it is published in its final form. Please note that during the production process errors may be discovered which could affect the content, and all legal disclaimers that apply to the journal pertain. 


\title{
A novel system for large-scale storage of electricity as synthetic natural gas using reversible pressurized solid oxide cells
}

\author{
Giacomo Butera $^{a, 1}$, Søren Højgaard Jensen ${ }^{b}$, Lasse Røngaard Clausena \\ a DTU Mechanical Engineering, Technical University of Denmark, Lyngby, 2800, DK. \\ b DTU Energy, Technical University of Denmark, Roskilde, 4000, DK. \\ ${ }^{1}$ Corresponding author e-mail: giabut@mek.dtu.dk
}

\begin{abstract}
The ongoing reduction of greenhouse gas emissions entails increased use of intermittent renewable energy technologies such as wind and solar. This raises the need for costeffective and efficient electricity storage. In particular seasonal variations in supply and demand will require tremendous storage capacity. In this paper we present a truly largescale electricity storage system which uses pressurized reversible solid oxide cells combined with catalytic reactors to store electricity as synthetic natural gas. By storing the produced gas in existing natural gas grids the system can create a strong and efficient link between the electricity and gas markets. In addition, the system is able to operate reversibly using gas from the grid to satisfy the electric power demand.

The system performance is analyzed with a component-based thermodynamic modeling tool which shows that electricity can be stored as synthetic natural gas with an energy efficiency of $89 \%$. The gas to electricity efficiency is equally high, resulting in a round-trip storage efficiency of $80 \%$ (DC-to-DC).

Keywords: Energy Storage, Solid Oxide Cells, Natural Gas Grid, Internal Methanation, Bio-syngas upgrading.
\end{abstract}

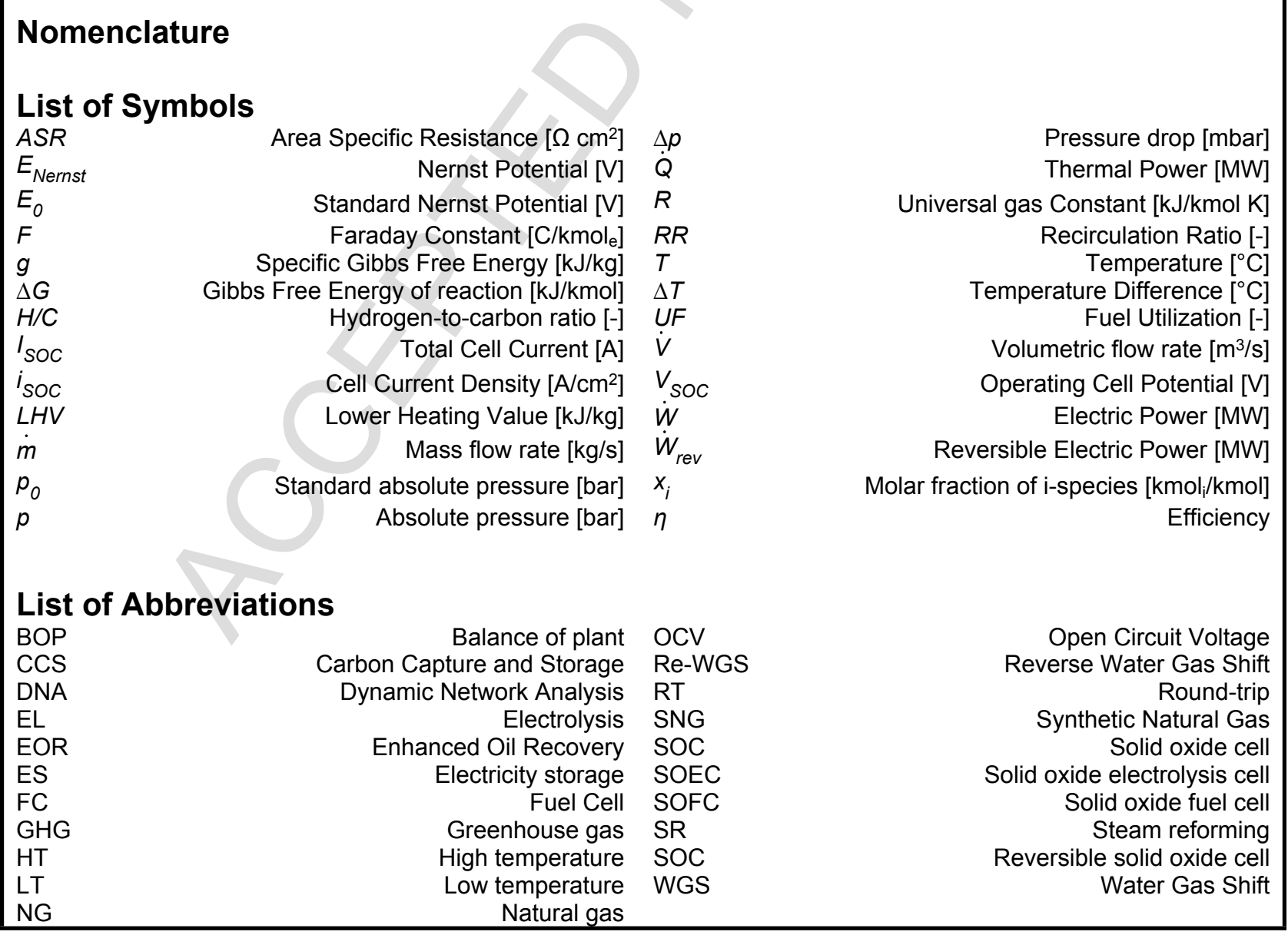




\section{Introduction}

With the growing number of parties ratifying the Paris agreement, latest consolidated on the UN Climate Change Conference in Bonn in November 2017, reduction of greenhouse gas emissions by increasing the energy supply from renewable sources becomes increasingly important in the forthcoming years [1-5]. A major obstacle related to this agenda is costcompetitive and efficient electricity storage (ES) to balance the intermittency of renewable sources with the fluctuations in the demand. This paper proposes a novel electricity storage system, integrating pressurized reversible solid oxide cells (SOCs) and catalytic reactors for the storage of electricity as synthetic natural gas (SNG). During electricity production a $\mathrm{CO}_{2}$ rich gas is produced. Subsurface storage of this gas ensures a closed storage loop without $\mathrm{CO}_{2}$ emission. Figure 1 provides a simplified scheme of the $\mathrm{ES}$ concept. Subsurface storage of $\mathrm{CO}_{2}$ is currently investigated in various carbon-capture and storage (CCS) projects [6], and is widely applied in enhanced oil recovery (EOR) [6-8]. Furthermore, in Europe 163 underground natural gas storages are currently in operation [9].

Pressurized SOCs with internal methanation used for ES constitute a relatively new concept, still far from being commercialized as e.g. steam electrolysis [10-12] or $\mathrm{CO}_{2}$-electrolysis [13] and characterized by a number of technical challenges to be addressed before a successful implementation [14]. However the concept has been analyzed in previous studies [15-18], as they are characterized by high efficiency and cost-effectiveness on large-scale [17]. Wendel et al. studied a small-scale ES plant utilizing SOCs [15], while Wendel et al. [16] and Jensen et al. [17] introduced and analyzed a large-scale ES system, both in terms of efficiency and economy. Jensen et al. found that a high round-trip efficiency was key to ensure high capacity factor and good plant economy [17]. Monti et al. integrated SOCs with a methane synthesis reactor in order to increase the energy density of the stored methane rich gas [18]. None of the cases presented above produces an output fuel whose methane content is high enough for a direct injection into the natural gas (NG) grid, meaning that a separate fuel storage system is needed. Production of SNG based on pressurized solid oxide electrolysis cells with internal methanation has been studied by Giglio et al. $[19,20]$ and by Luo et al. [21,22], but these systems are markedly different as they were not designed for reversible operation ${ }^{1}$. Luo et al. proposed a way to produce grid quality SNG in a single tubular SOEC reactor, conceived to have electrolysis and methanation taking place in the same reactor at high and low temperatures, respectively $[21,22]$. The reactor is only followed by a condenser to remove excess steam. The design of the single tubular SOEC reactor could be superior in terms of operation at different operating pressures for fuel and air. However, the use of a single dedicated reactor for $\mathrm{CH}_{4}$ synthesis is a well proven technology which translates into a lower cost. In addition, the compactness of planar SOC stacks allows easy scalability of the system.

Two types of chemical reactors have been employed in the ES plant presented in this paper. Methanation reactors are used in electrolysis mode (or power-to-gas (P2G) mode), to increase the molar fraction of methane in the outlet gas of the plant. The released heat is used to produce steam, required in electrolysis mode for the production of intermediate $\mathrm{H}_{2}$,

\footnotetext{
${ }_{1}^{1}$ Please see section 3 for a list of 5 key differences between these works and the present work. Only the low temperature methanator (point 4) is also imployed by Giglio et al. [19,20].
} 
but also to increase the $\mathrm{H} / \mathrm{C}$ ratio at the SOC fuel electrode to avoid carbon formation (coking) in the electrode. In gas-to-power mode (G2P or fuel cell mode), the SNG is prereformed in a specially designed recuperator that has catalytic material on the fuel side of the heat exchanger. This ensures an inlet fuel gas to the SOC which is close to chemical equilibrium, which is important for the thermal management of the SOC, but it also utilizes the sensible heat of the outlet fuel gas from the SOC. A humidifier-condenser loop provides steam required for operation of the SOCs with sufficiently high $\mathrm{H} / \mathrm{C}$ ratio. The new plant layout translates into a higher energy storage efficiency with respect to the plant analyzed by Wendel et al. [16] and Jensen et al. [17], and into storage of electricity as SNG.

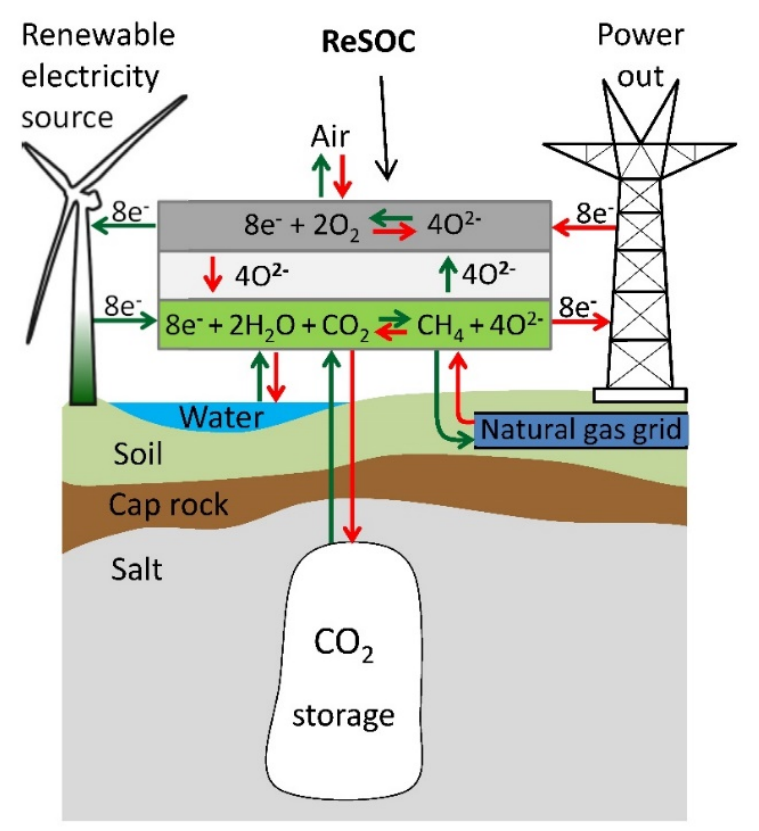

Figure 1: Schematic design of the novel ES plant storing electricity as $\mathrm{SNG}$. The name $\mathrm{CO}_{2}$ storage refers to a $\mathrm{CO}_{2}$ rich gas mixture. If the fuel utilization factor is low, the hydrogen content can be as high as the $\mathrm{CO}_{2}$ content.

\section{Reversible solid oxide cells}

The reversible SOC is the main component of the ES system presented in this paper. It is an electrochemical device having two electrodes, separated by a thin $\mathrm{O}^{2-}$-ion permeable electrolyte [23]. In P2G mode, the SOC operates as a solid oxide electrolysis cell (SOEC) reducing $\mathrm{H}_{2} \mathrm{O}$ and $\mathrm{CO}_{2}$ to $\mathrm{H}_{2}$ and $\mathrm{CO}$, respectively [23-25]. In G2P mode, the SOC operates as a solid oxide fuel cell (SOFC) oxidizing $\mathrm{H}_{2}$ and $\mathrm{CO}$ to $\mathrm{H}_{2} \mathrm{O}$ and $\mathrm{CO}_{2}$.

The SOC fuel electrode typically contains sub- $\mu \mathrm{m}$ sized dispersed Nickel particles. The Nickel particles form a percolated electron conducting network and participate in formation of electro-catalytic reaction sites for the electrode reactions. $\mathrm{Ni}$ is the preferred commercial catalyst for conversion of syngas to $\mathrm{CH}_{4}$, as well as for $\mathrm{CH}_{4}$ reforming $[26,27]$. By pressurizing the $\mathrm{SOC}$, the Nickel particles can catalytically form methane inside the fuel electrode in electrolysis mode via reaction (R.1) $[16,24]$ :

$$
3 \mathrm{H}_{2}+\mathrm{CO} \rightarrow \mathrm{CH}_{4}+\mathrm{H}_{2} \mathrm{O}
$$


The heat released by this reaction can be exploited to lower the thermo-neutral voltage, i.e. the potential at which the SOC works isothermally and adiabatically in electrolysis mode. Thus, despite the endothermic electrolysis reactions, the SOEC can operate exothermally at low electrode overvoltage.

Pressurized operation of an SOC stack with internal formation/reforming of $\mathrm{CH}_{4}$ have recently been experimentally investigated by Jensen et al. in [28]. The stack from SOFCMAN was operated with a $\mathrm{CO}_{2}$ and $\mathrm{H}_{2} \mathrm{O}$ rich gas at $700{ }^{\circ} \mathrm{C}$ and 18.7 bar. $\mathrm{The}^{\mathrm{CH}_{4}}$ content in the stack outlet gas increased from $0.22 \mathrm{~mol} \%$ at open circuit voltage (OCV) to $18 \mathrm{~mol} \%$ (dry basis) at $-0.17 \mathrm{~A} \mathrm{~cm}^{-2}$ in electrolysis mode. An increase in the $\mathrm{CH}_{4}$ content in the outlet gas is in line with the results predicted by chemical equilibrium.

From an overall point of view, the desired reaction in SOEC mode is reaction

$$
\begin{aligned}
2 \mathrm{H} 2 \mathrm{O}+\mathrm{CO}_{2} \rightarrow \mathrm{CH}_{4}+ & 2 \mathrm{O}_{2} . \\
& 2 \mathrm{H}_{2} \mathrm{O}+\mathrm{CO}_{2} \rightarrow \mathrm{CH}_{4}+2 \mathrm{O}_{2} .
\end{aligned}
$$

Concerning the fuel cell operation of the $\mathrm{SOCs}$, the excess heat released by the exothermic oxidation reactions is useful to promote $\mathrm{CH}_{4}$ conversion to $\mathrm{H}_{2}$ and $\mathrm{CO}$ through the steam reforming (SR) reaction (R.3):

$$
\mathrm{CH}_{4}+\mathrm{H}_{2} \mathrm{O} \rightarrow 3 \mathrm{H}_{2}+\mathrm{CO} \text {. }
$$

$\mathrm{SR}$ is an endothermic reaction helpful to cool down the SOFC, decreasing the mass flow rate of air needed to cool the stack and improving the cell performance.

This means the desired reaction in SOFC mode is reaction (R.4).

$$
\mathrm{CH}_{4}+2 \mathrm{O}_{2} \rightarrow 2 \mathrm{H}_{2} \mathrm{O}+\mathrm{CO}_{2} \text {. }
$$

Another reaction occurring inside the $\mathrm{SOC}$ is the water gas shift (WGS) reaction, shown in reaction (R.5):

$$
\mathrm{CO}+\mathrm{H}_{2} \mathrm{O} \rightarrow \mathrm{H}_{2}+\mathrm{CO}_{2} \text {. }
$$

The theoretical maximum roundtrip efficiency of the overall reaction (

$$
2 \mathrm{H} 2 \mathrm{O}+\mathrm{CO}_{2} \rightarrow \mathrm{CH}_{4}+2 \mathrm{O}_{2} \text {. }
$$

or (R.4)), can be calculated as the ratio between the in Gibbs free energy and the heat of the reaction $(\Delta \mathrm{G} / \Delta \mathrm{H})$. At standard conditions the reversible reaction will be endothermic in SOEC mode and exothermic in SOFC mode $(\Delta \mathrm{G} / \Delta \mathrm{H}=91.9 \%)$, resulting in a maximum roundtrip efficiency of $91.9 \%$. If water is not condensed but stored in vapor phase with the $\mathrm{CO}_{2}$ gas, as suggested by Wendel et al. [15], the reversible reaction will be almost balanced in both SOEC and SOFC mode $(\Delta \mathrm{G} / \Delta \mathrm{H}=99.8 \%)$, resulting in a maximum roundtrip efficiency of $99.8 \%$. As storage of water vapor gives several problems in terms of storage size, needed storage temperature and issues with corrosion and condensation in the storage, another option for raising the maximum roundtrip efficiency is pursued in this study. By changing the overall reaction to (R.6), it is possible to raise the maximum roundtrip efficiency to $96.1 \%$. The required storage volume is increased compared with pure $\mathrm{CO}_{2}$ storage

$$
2 \mathrm{H} 2 \mathrm{O}+\mathrm{CO}_{2} \rightarrow \mathrm{CH}_{4}+2 \mathrm{O}_{2} \text {. }
$$

as an equal amount of $\mathrm{H}_{2}$ is stored with the $\mathrm{CO}_{2}$.

$$
\mathrm{CH}_{4}+1.5 \mathrm{O}_{2} \rightarrow \mathrm{H}_{2} \mathrm{O}+\mathrm{H}_{2}+\mathrm{CO}_{2}
$$


Solid carbon forming reactions can occur at the fuel electrode of the SOC which can cause permanent damage to the fuel electrode. Nickel catalyzes the carbon formation so the fuel electrodes must be operated at conditions where carbon is not formed.

Figure 2(a) shows the gas atomic composition inside the reversible SOC fuel electrodes for the two operating modes. The carbon formation region (i.e. where the carbon activity is equal to 1 and where carbon is formed via the Boudouard reaction) at $700{ }^{\circ} \mathrm{C}$ and $18.7 \mathrm{bar}$ and the region where the fuel is fully oxidized is shown in grey and light blue respectively. The diagram was calculated using Factsage ${ }^{\mathrm{TM}}$. Note that the electrolysis mode reaches a lower oxygen content than the fuel cell mode, which causes the different minimum $\mathrm{H} / \mathrm{C}$ ratio in Figure 2(b).

(a)

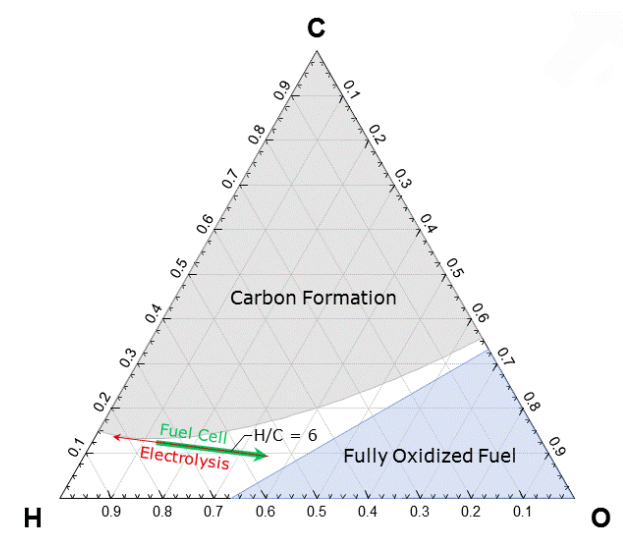

(b)

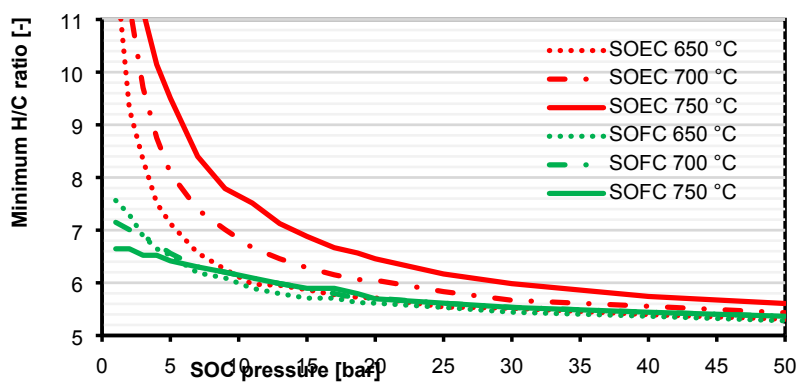

Figure 2: (a)Ternary diagram showing the two operation modes for the reversible SOC, the carbon formation region and the region with fully oxidized fuel at $700{ }^{\circ} \mathrm{C}$ and $18.7 \mathrm{bar}$; (b) Minimum $\mathrm{H} / \mathrm{C}$ ratios for electrolysis (SOEC) and fuel cell (SOFC) modes vs. stack pressure at different temperatures, to operate SOCs avoiding carbon formation. The minimum thermodynamic $\mathrm{H} / \mathrm{C}$ ratio is calculated using the software Factsage ${ }^{\mathrm{TM}} 7.2$.

A minimum hydrogen to carbon molar ratio is needed to avoid carbon formation inside the SOCs. The minimum $\mathrm{H} / \mathrm{C}$ ratio depends on the operating temperature and pressure. Figure 2(b) shows the minimum $\mathrm{H} / \mathrm{C}$ ratio as a function of the stack pressure at different temperatures for the two operating modes.

Note that at low pressure, the FC lines cross each other, meaning that at low pressure a low-temperature SOFC $\left(650^{\circ} \mathrm{C}\right)$ requires higher $\mathrm{H} / \mathrm{C}$ ratio than a high-temperature SOFC $\left(750{ }^{\circ} \mathrm{C}\right)$ to operate without risks of carbon formation [29]. Moreover, below 13 bar it will require perfect fuel flow uniformity in the $\mathrm{SOC}$ to operate at the minimum $\mathrm{H} / \mathrm{C}$ ratio in SOEC mode. This is because the carbon formation region is no longer tangential to the SOEC operating line below 13 bar.

\subsection{Modelling of SOC}

The system was modeled using the component-based modeling tool DNA (Dynamic Network Analysis) [30,31].

The SOC is characterized by the OCV, which is assumed equal to the average Nernst potential. The average Nernst potential can be calculated through energy and entropy balances on a control volume as represented in Figure 3. The power $\dot{W}_{\text {rev }}$ is either produced (positive) or consumed (negative) within the control volume, and is given by eq. (1) [32,33]: 


$$
\dot{W}_{\text {rev }}=\dot{m}_{\text {fuel, IN }} g_{\text {fuel,IN }}+\dot{m}_{\text {air, IN }} g_{\text {air, IN }}-\dot{m}_{\text {fuel,OUT }} g_{\text {fuel,OUT }}-\dot{m}_{\text {air, OUT }} g_{\text {air, OUT }}
$$

where $g$ represents specific Gibbs free energy of the various gas flow. The subscripts fuel and air specify the gas flow entering (or exiting) the fuel or air side. Note that it is important that $g$ is calculated at the operating temperature of the SOC. The model therefore assumes an isothermal SOC.

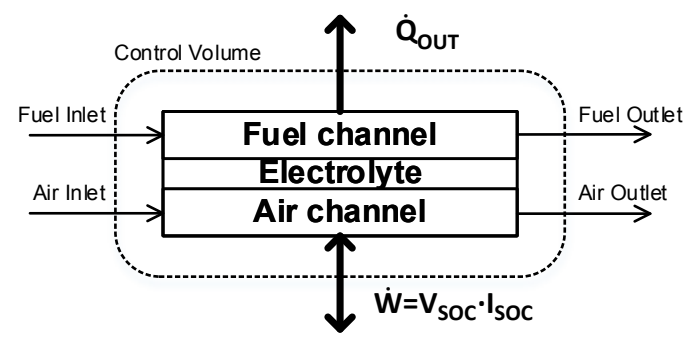

Figure 3: Control volume for a generic SOC.

The average Nernst potential $\left(E_{\text {Nernst,avg }}\right)$ is calculated using eq. (2) [32,33]:

$$
E_{\text {Nernst,avg }}=\frac{\dot{W}_{\text {rev }}}{l_{\text {soC }}} \text {, }
$$

where $I_{\text {SOC }}$ represents the total electric current in the SOC${ }^{2}$.

The SOFC and SOEC operating potential is different from the Nernst potential due to internal losses in the cell. Eq. (3) is used to calculate the operating voltage $V_{\text {SOC }}$ :

$$
V_{\text {SOC }}=E_{\text {Nernst, avg }}-A S R i_{\text {SOC }}
$$

where $A S R$ is the area specific resistance and $i_{\text {SOC }}$ is the SOC current density. It is important to ensure that the Nernst potential is always higher/lower than the cell potential $V_{\text {soc }}$ when the SOC operates as an SOFC/SOEC. To ensure this, inlet and outlet Nernst potentials are locally calculated using eq. (4):Error! Reference source not found.

$$
E_{\text {Nernst }}=-\frac{\Delta G}{n_{e} F}
$$

In eq. (4), $\Delta G$ is the Gibbs free energy of a general electrochemical reaction, $n_{e}$ the number of electrons transferred during the reaction and $F$ is the Faraday constant.

In the presented model work we assume the gas to be fully equilibrated, i.e. that the water gas shift and the reversible water gas shift reactions are assumed to be much faster than the electrolysis reactions [24,25,34-36]. For a fully equilibrated carbonaceous gas containing $\mathrm{O}, \mathrm{H}$ and $\mathrm{C}$, the Nernst potential can be calculated using eq. (5) :

$$
E_{\text {Nernst }}=E_{0}+\frac{R T}{n_{e} F} \ln \left(\frac{p^{0.5} x_{O_{2}{ }^{0.5} x_{2}}}{p_{0}^{0.5} x_{H_{2} \mathrm{O}}}\right) \text {. }
$$

In eq.(5), $E_{0}$ is the standard Nernst potential, $R$ the universal gas constant, $T$ the operating temperature, $p$ the operating pressure, $p_{0}$ the standard pressure and $x_{i}$ the molar fraction of

\footnotetext{
${ }^{2} \mathrm{~A}$ positive current refer to SOFC mode, and a negative current to SOEC mode.
} 
the $\mathrm{i}^{\text {th }}$ species. Eq. (5) is used to calculate the Nernst voltage at the SOC inlet and outlet for co- and counter-flow gas configuration.

The utilization factor UF expresses the conversion of reactants (equivalent $\mathrm{H}_{2}$ in SOFC I equivalent $\mathrm{H}_{2} \mathrm{O}$ in SOEC). Eqs. (6) and (7) show the UF for SOFC and SOEC, respectively:

$$
\begin{gathered}
U F_{S O F C}=\frac{2 \cdot \dot{n}_{\mathrm{O}_{2}, \text { transferred }}}{\dot{n}_{\mathrm{H}_{2}, \text { in }}+\dot{n}_{\mathrm{CO}, \text { in }}+4 \cdot \dot{n}_{\mathrm{CH}_{4}, \text { in }}}, \\
U F_{\mathrm{SOEC}}=\frac{2 \cdot \dot{n}_{\mathrm{O}_{2}, \text { transferred }}}{\dot{n}_{\mathrm{H}_{2} \mathrm{O}, \text { in }}+2 \cdot \dot{n}_{\mathrm{CO}_{2}, \mathrm{in}}+\dot{n}_{\mathrm{CO}, \mathrm{in}}},
\end{gathered}
$$

where $n$ represents the molar flow rates.

\section{System design}

A simplified flowsheet of the ES system can be seen in Figure 4. The design has been developed separately for the two modes of operation. Afterwards the two designs have been combined in order to ensure that most of the components can be used in both operating modes.

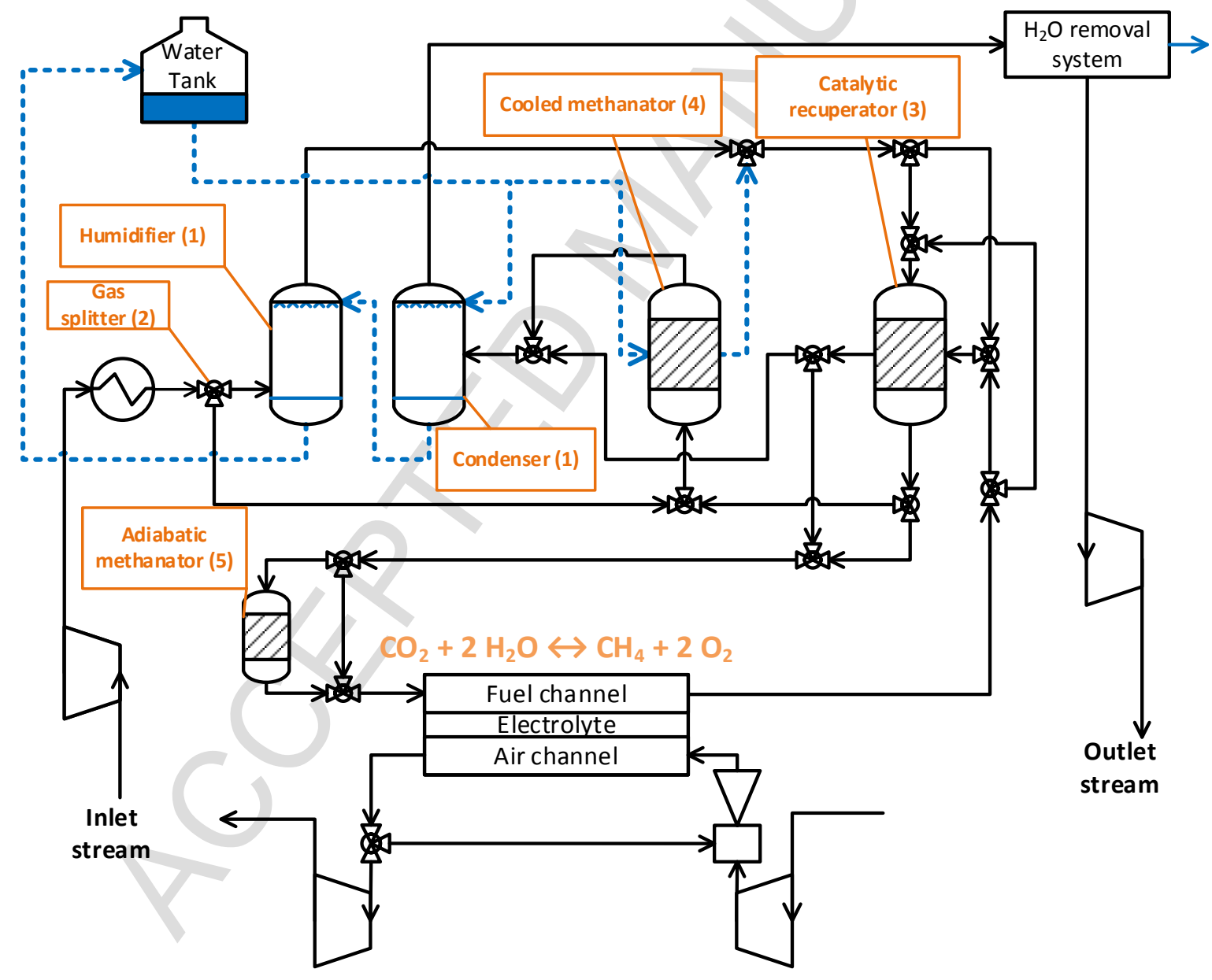

Figure 4: Simplified layout of the ES system. 
The system integrates heat exchangers and balance of plant (BOP) hardware with a number of new components ${ }^{3}$, which enables storage of electricity as SNG instead of a methane rich gas $\left(61 \mathrm{~mol} \% \mathrm{CH}_{4}, 38 \mathrm{~mol} \% \mathrm{H}_{2}\right)$ as previously proposed [16,17]. In addition, the presented ES system achieves a significantly higher storage efficiency compared to previously reported ES systems.

The following components have been introduced: 1) a humidifier-condenser loop, 2) a gas splitter, 3) a catalytic recuperator, 4) a cooled methanator and 5) an adiabatic methanator.

1) The humidifier is used to provide the required steam for the SOCs. Here hot liquid water can be used instead of saturated steam from an evaporator. Thus, the heat can be provided at temperatures lower than the evaporation temperature of water at the operating pressure. The heat necessary for saturating the gas stream entering the humidifier is provided by the condenser (Figure 4). The cold water entering the condenser cools the gas downstream the SOC: the temperature drop results in the decrease of the water saturation pressure and a subsequent release of condensed $\mathrm{H}_{2} \mathrm{O}$ from the gas. In addition, the heat transfer between hot gas and liquid water results in an increased temperature of water exiting the condenser in the bottom. The hot liquid water can hence be used in the humidifier.

2) The gas splitter is used in $\mathrm{P} 2 \mathrm{G}$ mode to split the $\mathrm{CO}_{2}$-rich gas coming from the storage. The main flow is sent to the humidifier and to the SOC, while the remaining part is mixed with the fuel produced in the SOEC to increase the $\mathrm{CO}_{2}$ fraction at the inlet of the cooled methanation reactor. In this way, the excess hydrogen in the fuel gas from the SOEC is converted to $\mathrm{CH}_{4}$.

3) The catalytic recuperator has catalytic material on the fuel side, and is used to preheat reactants in both modes, exploiting the hot product gasses from the SOC. In G2P mode, the $\mathrm{CH}_{4}$-rich fuel is reformed before entering the SOFC. The hot product gas from the SOFC contains enough sensible heat to allow a significant reforming. The catalytic effect of the recuperator does not play an important role in P2G mode because the $\mathrm{CO}$ and $\mathrm{CO}_{2}$ content in the fuel gas from the SOEC is very low, meaning that very little methane is formed when cooling the gas through the recuperator ${ }^{4}$.

4) In P2G mode, the cooled methanator is used downstream the SOEC, which substantially increases the methane content. The cooling is provided by steam generation. The steam is needed to operate the SOEC with the minimum $\mathrm{H} / \mathrm{C}$ ratio.

5) The adiabatic methanator is used before the $S O C$ in $P 2 G$ mode to heat the gas to the SOEC inlet temperature $\left(\sim 600^{\circ} \mathrm{C}\right)$ through the exothermic $\mathrm{CH}_{4}$ synthesis.

In the presented modeling study, the composition of the SNG produced in the P2G mode corresponds to the composition of the inlet flow for the G2P mode. This assumption is true if the SNG is not injected into the NG grid but stored separately. If the produced SNG is injected into the NG grid, the inlet gas flow in G2P mode will depend on the composition of the NG in the national pipeline system, and will slightly differ from the SNG produced in the P2G mode. Nevertheless, the composition of the SNG produced in P2G mode will always be constant since it is set by the conditions in the cooled methanation reactor. Conversely,

\footnotetext{
${ }^{3}$ Differently combined or not employed in previous studies.

${ }^{4}$ The catalytic effect is therefore ignored in $\mathrm{P} 2 \mathrm{G}$ mode.
} 
the composition of the $\mathrm{CO}_{2}$-rich mixture produced in $\mathrm{G} 2 \mathrm{P}$ mode corresponds to the inlet composition to the $\mathrm{P} 2 \mathrm{G}$ mode.

\subsection{P2G mode}

During electricity storage operation, the SOC works as an SOEC and electricity is consumed to produce a $\mathrm{CH}_{4}$-rich stream (SNG) to be stored in the $\mathrm{NG}$ grid. Figure 5 provides a simplified layout for the ES plant in P2G mode. A detailed layout is provided in Appendix A. The $\mathrm{CO}_{2}$-rich stream, produced and stored in $\mathrm{G} 2 \mathrm{P}$ mode, is expanded and heated. After the splitter, the main flow goes through the humidifier, where it is enriched with steam. It is then mixed with steam generated in the cooled methanation reactor and then heated to the SOEC inlet temperature by the gas recuperator and the adiabatic pre-methanator. The fuel produced in the SOEC is cooled and mixed with the smaller stream of $\mathrm{CO}_{2}$-rich gas previously separated with the splitter. The mixed gas is sent to the cooled methanator where almost all the carbon is fixed as $\mathrm{CH}_{4}$. The $\mathrm{CH}_{4}$-rich stream is then cooled in the condensers in order to remove water. A water removal system is necessary to remove the remaining $\mathrm{H}_{2} \mathrm{O}$ and meet the constraints imposed by the NG grid connection. The resulting SNG can then be compressed and injected to the NG grid.

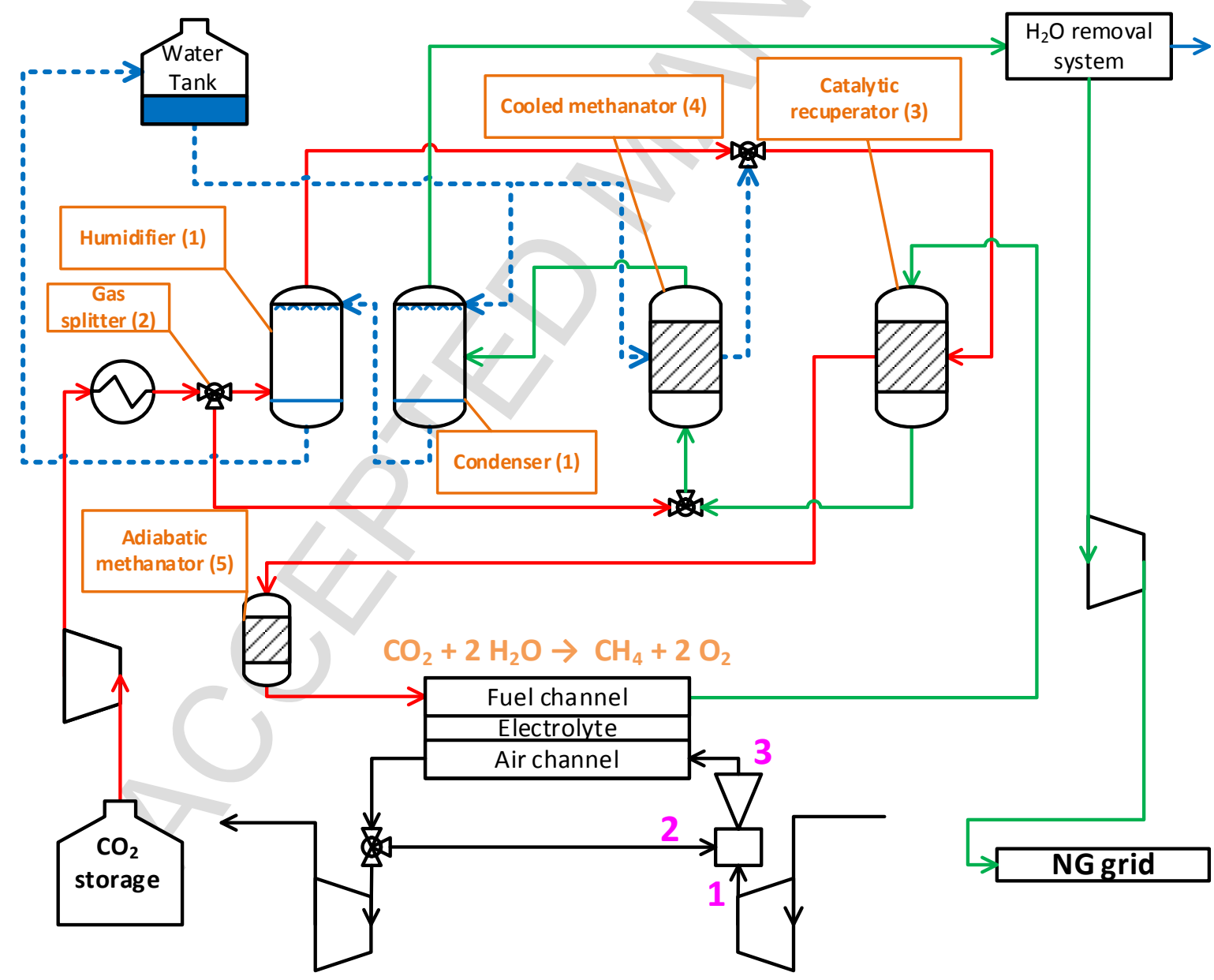

Figure 5: Simplified diagram of the ES plant in P2G mode. Red pipelines represent the $\mathrm{CO}_{2}$-rich gas flows. Green pipelines represent $\mathrm{CH}_{4}$-rich gas flows. Numbers 1-3 refer to the inlet and outlet nodes of the ejector in eq. (8) ). 


\subsubsection{Process design parameters for the $P 2 G$ mode}

The parameters used in both P2G and G2P mode are presented in Table 1 and Table 2. An ejector is used to recycle oxidant on the air side of the SOCs, which is similar to a previous ES plant layout [16]. The ejector is modeled by eq. (8):

$$
\eta_{\text {EJECTOR }}=\frac{\dot{V}_{2} p_{2} \ln \left(p_{3} / p_{2}\right)}{\dot{V}_{1}\left(p_{1}-p_{3}\right)},
$$

where $\eta_{\text {EJECTOR }}$ is the ejector efficiency, and $\dot{V}$ and $p$ represent the volumetric flow rates and pressures of the primary driving flow (1), recycled oxidant (2) and discharge flow (3) (see numbers on Figure 5). The SOC ASR has been set to a constant value of $0.2 \Omega \mathrm{cm}^{2}$ as in previous modeling works $[16,17]$, despite it highly depends on temperature and, in lower extent, on pressure. The temperature dependency of the SOC ASR is discussed as a part of the parameter variation study in section 4 . Inlet and outlet temperatures of the SOCs are set constant, whereas a maximum temperature increase of $\sim 100^{\circ} \mathrm{C}$ across both the fuel and air channels is allowed to avoid extreme thermal stresses inside the SOC. The pressure drop $\Delta p_{\text {SOC }}$ is set to $30 \mathrm{mbar}$ for both fuel and air side, whereas no pressure drops are considered for the BOP hardware. A preliminary investigation has shown that pressure drops on the fuel side has a very small effect on the system performance. This is due to a relatively small fuel flow, and pressurized reactant/product storage ${ }^{5}$. The impact of the pressure drops of the air side BOP on the efficiency is higher with respect to the fuel side, but these losses are already implicitly considered when setting an air turbine discharge pressure of 1.1 bar. The $H / C$ ratio is set to be the minimum value required during electrolysis to avoid carbon formation, according to Figure 2(b).

The humidifier and the high temperature $(\mathrm{HT})$ and low temperature $(\mathrm{LT})$ condensers (detailed diagram in Appendix A) are characterized by a minimum temperature difference between the hot and cold flows of $5{ }^{\circ} \mathrm{C}$, which is lower than the minimum temperature difference assumed for the heat exchangers $\left(10^{\circ} \mathrm{C} / 30^{\circ} \mathrm{C}\right)$ because of direct contact between gas and liquid in the humidifier and condensers.

The storage of the $\mathrm{CO}_{2}$-rich gas is operated at 140 bar to avoid $\mathrm{CO}_{2}$ condensation. In case of underground storage of the gas in a cavern, the natural temperature gradient in the ground $\left(25-30{ }^{\circ} \mathrm{C} / \mathrm{km}[37]\right)$ will ensure a temperature higher than the saturation temperature of $\mathrm{CO}_{2}$. The injection pressure of the SNG in the NG grid has been assumed equal to 80 bar [38], which corresponds to the maximum pressure in the Danish NG transmission lines. In case the pipeline pressure differs from the assumption made in this paper, preliminary modeling has shown it would have almost no effect on the efficiency and the operation of the ES. The injection temperature of the SNG should be between $0{ }^{\circ} \mathrm{C}$ and $50{ }^{\circ} \mathrm{C}$ [39], whereas the

\footnotetext{
${ }^{5}$ For example, if a pressure drop of 2.5 bar is added both before and after the SOC, it means that the storage turbine will expand from the storage pressure (80 bar for natural gas, or 140 bar for $\mathrm{CO}_{2}$ ) to the operating pressure +2.5 bar ( 21.5 bar instead of $\sim 19$ bar), and the SNG or $\mathrm{CO}_{2}$ compressor will need to compress from $\sim 16$ bar instead of $\sim 19$ bar to the storage pressure (80 bar for the natural gas grid, or 140 bar for $\mathrm{CO}_{2}$ ). The total added compressor power and lost turbine power is $0.2 \mathrm{MW}$ in P2G mode and $0.2 \mathrm{MW}$ in G2P mode, corresponding to a reduction of the RT efficiency of $0.4 \%$-points.
} 
maximum dew point temperature should be $-8^{\circ} \mathrm{C}$ [39], resulting in a maximum molar fraction of $\mathrm{H}_{2} \mathrm{O}$ of 39 ppm at 80 bar.

Table 1: Plant process design parameters used for both $P 2 G$ and G2P modes.

\begin{tabular}{|c|c|c|c|}
\hline$\eta_{\text {EJECTOR }}$ & 0.20 & $\Delta p_{\text {SOC, air channel }}[\mathrm{mbar}]$ & 30 \\
\hline Active Area $\left[\mathrm{m}^{2}\right]$ & 20000 & $\Delta p_{B O P}[\mathrm{mbar}]$ & 0 \\
\hline$A S R\left[\Omega \mathrm{cm}^{2}\right]$ & 0.20 & $\eta_{\text {compressor, is }}$ & 0.88 \\
\hline$\Delta T_{\text {SOC,fuel channel }}\left[{ }^{\circ} \mathrm{C}\right]$ & 100 & $\eta_{\text {compressor,mech }}$ & 0.98 \\
\hline$\Delta T_{\text {SOC, air channel }}\left[{ }^{\circ} \mathrm{C}\right]$ & 100 & $\eta_{\text {turbine, is }}$ & 0.90 \\
\hline$\Delta T_{\text {outlets, } R e-s o c}\left[{ }^{\circ} \mathrm{C}\right]$ & 0 & $p_{\text {storage - exhausts }}[\mathrm{b}$ & 140 \\
\hline$\Delta T_{M I N, \text { gas - gas }}\left[{ }^{\circ} \mathrm{C}\right]$ & 30 & $p_{S N G-\text { injected }}[\mathrm{bar}]$ & 80 \\
\hline$\Delta T_{M I N, \text { gas - liq }}\left[{ }^{\circ} \mathrm{C}\right]$ & 10 & $T_{\text {SNG - injected }}\left[{ }^{\circ} \mathrm{C}\right]$ & 30 \\
\hline$\Delta T_{\text {MIN, humidifier }}\left[{ }^{\circ} \mathrm{C}\right]$ & 5 & $x_{\mathrm{H}_{2} \mathrm{O}, \mathrm{SNG} \text { - injected }}[\mathrm{ppm}]$ & 39 \\
\hline$\Delta T_{M I N, \text { condenser }}\left[{ }^{\circ} \mathrm{C}\right]$ & 5 & $p_{\text {discharge, air - turbine }}[\mathrm{bar}]$ & 1.1 \\
\hline$\Delta p_{\text {Soc,fuel channel }}[\mathrm{mbar}]$ & 30 & & \\
\hline
\end{tabular}

Table 2 provides the main parameters used for the SOEC in the P2G mode. The current density is set to $-0.5 \mathrm{~A} / \mathrm{cm}^{2}$, which is seen as a reasonable compromise between efficiency and capital cost, also considering that a low current density could extend the SOC lifetime. Importantly, the temperature of the stack was set to $700{ }^{\circ} \mathrm{C}$, instead of $650{ }^{\circ} \mathrm{C}$ used in previous studies [16,17], to simulate the use of near commercial SOCs. However, commercial SOC are characterized by an $A S R$ higher than $0.2 \Omega \mathrm{cm}^{2}$ used in this work: for instance a $1 \mathrm{~kW}$-electric-power stack from Elcogen has an $A S R$ of $0.37 \Omega \mathrm{cm}^{2}$ at $700{ }^{\circ} \mathrm{C}$ and atmospheric pressure, with a degradation rate of $22 \mathrm{~m} \Omega \mathrm{cm}^{2} / \mathrm{kh}$ [11]. Furthermore, single cell SOC's have shown ASR values as low as $0.17 \Omega \mathrm{cm}^{2}$ [11], making a stack ASR of $0.2 \Omega \mathrm{cm}^{2}$ realistic in the near future. The SOC operating pressure was calculated in G2P mode as described in Section G2P mode below. Pressure is an important parameter for the operation of the SOC as it affects both Nernst potential and ASR. Particularly, high pressure operation of the SOC is beneficial for the reduction of the ASR $[14,40]$, resulting also in an increase of the Nernst potential. The sum of the molar fractions of $\mathrm{H}_{2} \mathrm{O}$ and $\mathrm{CO}_{2}\left(\mathrm{X}_{\mathrm{H}_{2} \mathrm{O}}+\right.$ $\left.x_{\mathrm{CO}_{2}}\right)$ at the outlet of the SOEC has been set, instead of using a specific value for the UF.

Table 2: Process design parameters for the SOEC and LT methanator in P2G mode, SOFC and catalytic recuperator in G2P mode.

\begin{tabular}{lrr}
\hline Variable & P2G & G2P \\
\hline Utilization Factor $(U F)$ & $-{ }^{*}$ & 0.73 \\
$i_{\mathrm{SOC}}\left[\mathrm{A} / \mathrm{cm}^{2}\right]$ & -0.50 & 0.5 \\
$x_{\mathrm{H}_{2} \mathrm{O}}+x_{\mathrm{CO}_{2} \text { outlet }}$ & 0.10 & $-^{*}$ \\
$T_{\mathrm{SOC}}\left[{ }^{\circ} \mathrm{C}\right]$ & 700 & 700 \\
$p[$ bar $]$ & 18.7 & $-^{*}$ \\
$\mathrm{H} / \mathrm{C}$ & 6.07 & 5.99
\end{tabular}


$T_{\text {methanation, }, N}\left[{ }^{\circ} \mathrm{C}\right]$

$T_{\text {methanation,OUT }}\left[{ }^{\circ} \mathrm{C}\right]$

$\left.\Delta T_{\text {min, catalytic recuperator }}{ }^{\circ} \mathrm{C}\right]$

Note: "-*" means that the parameter is not an input but an output of the model.

\subsection{G2P mode}

Figure 6 shows a simplified flowsheet of the ES system in G2P mode. Here the SOC works as an SOFC where electricity is produced by converting the $\mathrm{CH}_{4}$-rich stream into a $\mathrm{CO}_{2}$-rich stream. More specific, the fuel is expanded, heated and sent to the humidifier, where steam is supplied to reach the required $\mathrm{H} / \mathrm{C}$ ratio for a non-coking SOEC operation condition. The saturated stream enters the fuel side of the catalytic recuperator, where it is pre-reformed. The pre-reformed fuel enters the SOFC, where it is oxidized and electric power is produced. The $\mathrm{CO}_{2}$-rich flow is cooled in the catalytic recuperator and water is removed by the condenser and a water removal system. The dry $\mathrm{CO}_{2}$-rich mixture is finally compressed and stored. In Appendix B, a detailed flowsheet of the ES plant in G2P mode is provided.

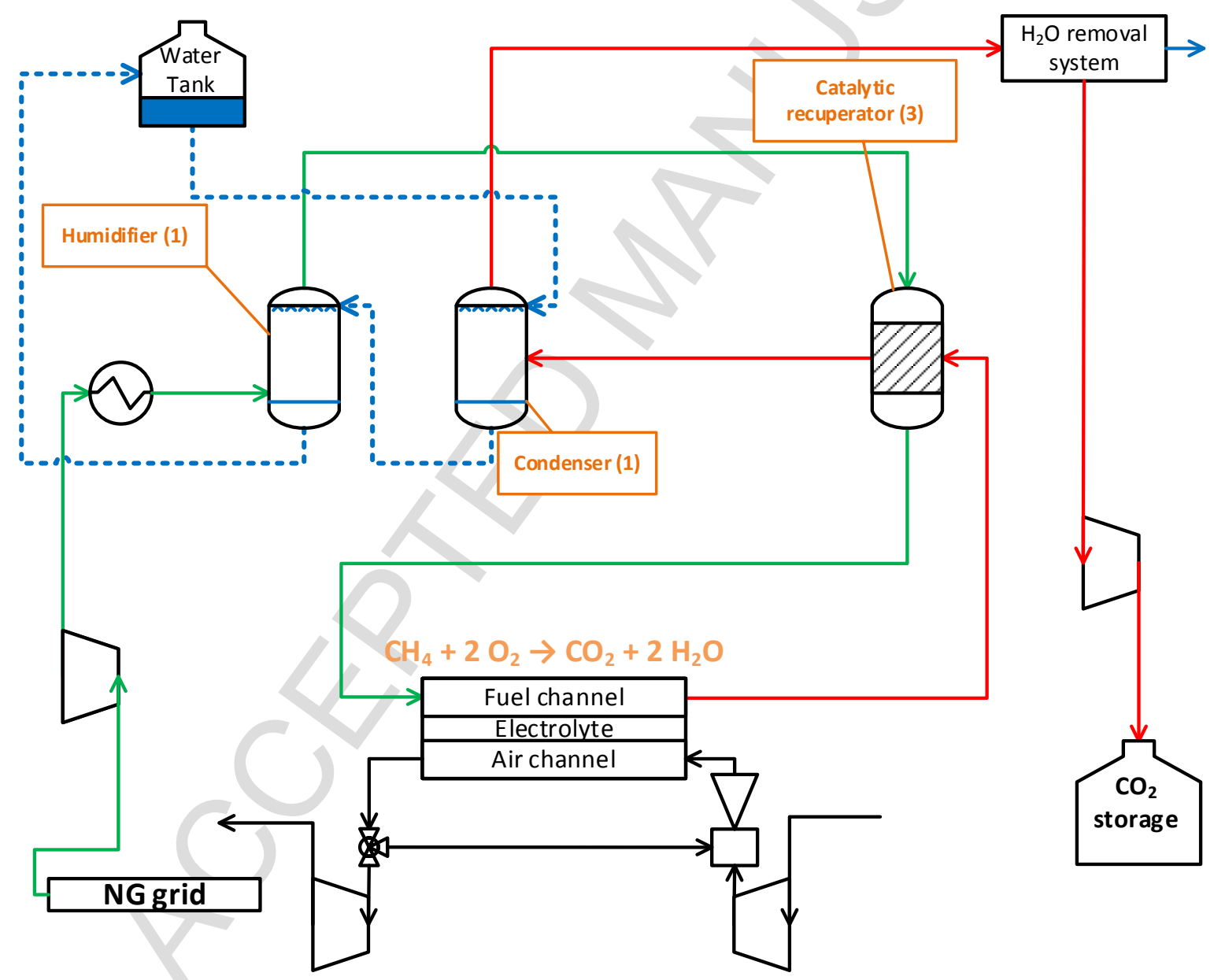

Figure 6: Simplified diagram of the ES plant in G2P mode. Red pipelines represent the $\mathrm{CO}_{2}$-rich mixture. Green pipelines represents $\mathrm{CH}_{4}$-rich mixture.

\subsubsection{Process design parameters for the G2P mode}

The same plant process design parameters used in P2G mode (listed in Table 1) are also used in fuel cell mode. Table 2 contains data about SOFC and the catalytic recuperator 
employed in G2P mode. The current density is kept at $0.5 \mathrm{~A} / \mathrm{cm}^{2}$, whereas the $\mathrm{H} / \mathrm{C}$ ratio is slightly higher than the minimum value to avoid carbon formation inside the SOCs, shown in Figure 2(b). The UF is kept low, to avoid a highly exothermic SOC operation. This increases the electricity storage efficiency, and results in a high $\mathrm{H}_{2}$ content in the stored $\mathrm{CO}_{2}$-rich gas, which is beneficial for the P2G mode. The SOC operating pressure was calculated by assuming a minimum temperature difference in the catalytic recuperator of 30 ${ }^{\circ} \mathrm{C}$. This minimum temperature difference is located inside the recuperator while the temperature difference at inlet and outlet is much higher. This is due to the endothermic steam reforming reactions. The need for a minimum temperature difference of $30^{\circ} \mathrm{C}$ inside the recuperator and to keep the SOFC inlet temperature at $600{ }^{\circ} \mathrm{C}$, makes SOC operating pressure the parameter to be varied in order to match the heat available and the heat required ${ }^{6}$ by the cold reacting gas in the catalytic recuperator. The calculated pressure is then set as input to the P2G mode (Table 2). The SOC operating pressure is always kept the same for both $\mathrm{G} 2 \mathrm{P}$ and $\mathrm{P} 2 \mathrm{G}$ in the whole study, to avoid a pressure variation when switching operation.

\subsection{Performance analysis}

The performance of the ES system is analyzed with respect to various key parameters. The main efficiency parameters are the roundtrip (RT) efficiencies, which have been defined for both the stack level (eq. (9)) and for the whole ES plant (eq. (10)) ${ }^{7}$ :

$$
\begin{gathered}
\eta_{R T-S T A C K}=\frac{V_{S O F C}}{V_{S O E C}}, \\
\eta_{R T-S Y S T E M}=\frac{\dot{W}_{S O C-G 2 P}+\dot{W}_{B O P-G 2 P}}{\left|\dot{W}_{S O C-P 2 G}+\dot{W}_{B O P-P 2 G}\right|},
\end{gathered}
$$

where $V_{S O E C}$ and $V_{S O F C}$ represent the cell operating voltage in the two operating modes, $\dot{\mathrm{W}}_{\text {SOC - P2G }}$ is the electric power consumed by the SOCs in electrolysis mode, $\dot{W}_{\text {SOC - G2P }}$ is the electric power produced by the SOCs in fuel cell mode, $\dot{W}_{B O P \text { - P2G }}$ and $\dot{W}_{B O P \text { - G2P }}$ are the BOP hardware electric power consumption (negative) or production (positive) in the two operating modes.

Mode-specific efficiency parameters are given in eqs. (11) - (14). These parameters are defined both for the stack and the whole plant:

$$
\begin{gathered}
\eta_{S O E C}=\frac{\dot{m}_{O U T-S O E C}\left(L H V_{O U T-S O E C}\right)-\dot{m}_{I N-S O E C}\left(L H V_{I N-S O E C}\right)}{\left|\dot{W}_{S O C-P 2 G}\right|}, \\
\eta_{P 2 G}=\frac{\dot{m}_{S N G} L H V_{S N G}-\dot{m}_{C O_{2}} L H V_{C O_{2}}}{\left|\dot{W}_{S O C-P 2 G}+\dot{W}_{B O P-P 2 G}\right|},
\end{gathered}
$$

\footnotetext{
${ }^{6}$ The heat required by the cold reacting $\mathrm{CH}_{4}$-rich gas depends on the outlet temperature and pressure of the catalytic recuperator, as they affects the composition at the thermodynamic equilibrium.

${ }^{7}$ RT efficiencies presented in this paper refer to DC-DC electricity conversion. AC/DC losses are not included.
} 


$$
\begin{gathered}
\eta_{S O F C}=\frac{\dot{W}_{S O C-G 2 P}}{\dot{m}_{I N-S O F C}\left(L H V_{I N-S O F C}\right)-\dot{m}_{O U T-S O F C}\left(L H V_{O U T-S O F C}\right)}, \\
\eta_{G 2 P}=\frac{\dot{W}_{S O C-G 2 P}+\dot{W}_{B O P-G 2 P}}{\dot{m}_{S N G} L H V_{S N G}-\dot{m}_{C O_{2}} L H V_{C O}} .
\end{gathered}
$$

In the eqs. (11) - (14), $\dot{m}$ represents the mass flow rates and $L H V$ the lower heating value of a flow. Subscripts OUT-SOEC (or OUT-SOFC) and IN-SOEC (or IN-SOFC) refer to the outlet and inlet nodes of the SOCs, whereas SNG and $\mathrm{CO}_{2}$ refer to the injected SNG or stored $\mathrm{CO}_{2}$-rich gas. Note that the system RT efficiency in eq. (10) can be also calculated multiplying eq. (12) and eq. (14). Conversely, since the composition of the inlet SOEC flow does not correspond to the outlet flow of the SOFC and also the outlet SOEC flow does not correspond to the inlet SOFC flow, the product of eq. (11) and eq. (13) does not represent the $\eta_{S T A C K}-R T$

\section{Results}

This section shows the main results obtained from the modeling of the ES plant. The results are presented first for the P2G and G2P modes followed by the stack and plant RT efficiencies. Subsequently a parametric analysis is given. Possible solutions to improve the operating conditions for the SOC are also provided.

\subsection{P2G mode}

Table 3 presents the main results obtained from the DNA modeling of the P2G mode. It can be seen that the calculated operating cell voltage is higher than the inlet and outlet Nernst potentials for both co- and counter-flow configurations, although the co-flow overvoltage at the stack outlet is only $27 \mathrm{mV}$ per cell due to the relatively high gas conversion ratio of 0.93 $(U F)$. The discussion about other effects related the choice of co- or counter-flow configuration of the SOC is beyond the scope of this work. Please note that the operating voltage of $1.141 \mathrm{~V}$ is higher than the thermoneutral voltage, resulting in exothermic SOC operation. The high UF is discussed in section 4.4 .4 below.

Table 3: Modeling results for the P2G and G2P modes.

\begin{tabular}{lrr}
\hline Variable & $\mathrm{P} 2 \mathrm{G}$ & $\mathrm{G} 2 \mathrm{P}$ \\
\hline $\mathrm{E}_{\text {Nernst }}[\mathrm{V}]$ & 1.041 & 1.007 \\
$\mathrm{~V}_{\mathrm{SOC}}[\mathrm{V}]$ & 1.141 & 0.907 \\
$p$ [bar] & $-^{*}$ & 18.7 \\
\hline
\end{tabular}




\begin{tabular}{lrr}
\hline$x_{\mathrm{O}_{2}}$ (SOC outlet) & 0.42 & -* $^{*}$ \\
$U F^{8}$ & 0.93 & $-^{*}$ \\
$E_{\text {Nernst co - flow inlet }}[\mathrm{V}]$ & 1.009 & 1.042 \\
$E_{\text {Nernst counter - flow inlet }}[\mathrm{V}]$ & 1.013 & 1.021 \\
$E_{\text {Nernst co - flow outlet }}[\mathrm{V}]$ & 1.114 & 0.957 \\
$E_{\text {Nernst counter - flow outlet }}[\mathrm{V}]$ & 1.109 & 0.981 \\
$\dot{W}_{B O P}[\mathrm{MW}]^{a}$ & 5.9 & -4.7 \\
$\dot{W}_{\text {SOC }}[\mathrm{MW}]$ & -114.1 & 90.7 \\
$\eta_{S O E C / S O F C}$ & $93.1 \%$ & $90.0 \%$ \\
$\eta_{P 2 G / G 2 P}$ & $89.3 \%$ & $89.1 \%$ \\
\hline
\end{tabular}

Note: "-*" means that the parameter is not an output but an input of the model. ${ }^{a}$ The work needed by the liquid water pumps are neglected as it is insignificant in this overall evaluation.

In P2G mode, the BOP components have a net power production because the air turbine mass flow is higher than the air compressor mass flow. Despite the positive BOP contribution, the stack electrolysis efficiency $\eta_{\text {SOEC }}$ is higher than the system efficiency $\eta_{P 2 G}$ because the methane production in the cooled methanator decreases the LHV of the output fuel flow, which decreases the overall efficiency. A detailed flowsheet including mass flows, temperatures and gas compositions can be found in appendix $\mathrm{A}$.

\subsection{G2P mode}

Table 3 reports the main modeling results for the G2P mode. The operating pressure is calculated to 18.7 bar by the DNA model after setting a minimum temperature difference of $30{ }^{\circ} \mathrm{C}$ in the catalytic recuperator. The $\mathrm{G} 2 \mathrm{P}$ efficiency $\eta_{\mathrm{G} 2 P}$ is seen to be equally high as the P2G efficiency $\eta_{P 2 G}$, this is mainly possible because the UF is low, meaning that the SOFC is mainly cooled by internal reforming instead of air. However, the low UF results in a $\mathrm{H}_{2}$ content which is almost as high as the $\mathrm{CO}_{2}$ content of the stored gas (Table 4). Table 3 shows that the BOP hardware consumes electric power in G2P mode. The stack efficiency $\eta_{\text {SOFC }}$ is thus higher than the system efficiency $\eta_{G 2 P}$. The overvoltage is $\sim 50 \mathrm{mV}$ per cell at the stack outlet of the SOFC. A detailed flowsheet including mass flows, temperatures and gas compositions can be found in Appendix B. When comparing the detailed flow sheets for the two operating modes it is clear that some components have significant load variations. This includes turbomachinery and heat exchangers. These components will have to be sized based on the most demanding mode, and then operate in part load in the other mode. Further implications on using the same components in both modes is beyond the scope of this work.

\subsection{RT efficiencies and composition of the stored gasses}

When considering the performance of the overall plant, the storage efficiency, i.e. the electricity-to-gas-to-electricity efficiency is a key parameter. This parameter is also called the system RT efficiency, and is calculated by eq. (10) to $79.6 \%$, meaning that if $100 \mathrm{MWh}$

\footnotetext{
${ }^{8}$ The utilization factor UF for electrolysis has been defined as the molar flow rate of O-atoms removed with respect to the molar flow rate of O-atoms entering the fuel channel of the SOC.
} 
of electricity is stored, then 79.6 MWh of electricity can be produced at a later point in time. It should be noted that since the SOC stack produces/consumes a DC current, losses in rectifiers and inverters required to interface with the existing power grid is not included in the RT efficiency. If included, the efficiency would drop to $\sim 76-79 \%$ (AC-to-AC), based on modern power electronics used in commercial battery energy storage solutions (BESS) [41]. The stack RT efficiency is calculated to be $79.5 \%$ (eq. (9)Error! Reference source not found.), which is practically the same as the system RT efficiency. The reason for this, as mentioned above at the $\mathrm{P} 2 \mathrm{G}$ mode, is that the BOP has a net power production in $\mathrm{P} 2 \mathrm{G}$ mode.

Table 4 shows the molar composition of the stored gasses. The most important data from this table is the molar fraction of $\mathrm{CH}_{4}$ in the output fuel produced in $\mathrm{P} 2 \mathrm{G}$ mode $(97.2 \mathrm{~mol} \%)$.

Table 4: Molar composition of the stored fuel gas and the stored $\mathrm{CO}_{2}$-rich gas.

\begin{tabular}{lcccc}
\hline & $\mathrm{H}_{2}$ & $\mathrm{CO}$ & $\mathrm{CO}_{2}$ & $\mathrm{CH}_{4}$ \\
\hline fuel gas [mol\%] & 2.2 & $\sim 0$ & 0.6 & 97.2 \\
$\mathrm{CO}_{2}$-rich gas [mol\%] & 41.6 & 9.4 & 46.1 & 2.9 \\
\hline
\end{tabular}

\subsection{Parametric analysis}

Selected parameters have been varied to evaluate the system response and impact on the RT efficiency. The parameters are $\mathrm{H} / \mathrm{C}$ ratio, SOFC gas inlet temperature, and SOC operating temperature. During the parametric analysis the design of the base system was slightly modified to meet the process design constraints. A list of the design changes, as well as the criteria for their implementation is given in Table 5. The implementation of any of the three design changes is primarily related to an increase in the operating pressure, and any of the three design changes results in a reduction of the plant RT efficiency.

Table 5: List of design changes of the operating modes during the parametric analysis including criteria for implementation and impact.

\begin{tabular}{|c|c|c|c|}
\hline $\begin{array}{l}\text { Design } \\
\text { change }\end{array}$ & Change & Criteria & Impact \\
\hline $\begin{array}{l}\text { P2G- } \\
\text { economizer }\end{array}$ & $\begin{array}{l}\text { The economizer (nodes } 49-50 \text { in } \\
\text { Figure A.1), for water preheating, } \\
\text { placed after the two air turbines, is } \\
\text { moved between the two air turbines. }\end{array}$ & $\begin{array}{l}\text { When increasing the operating } \\
\text { pressure the outlet temperature of } \\
\text { the air turbines is reduced. At a } \\
\text { certain point the } \Delta T_{\min } \text { of } 10^{\circ} \mathrm{C} \text { is } \\
\text { violated in the economizer. }\end{array}$ & $\begin{array}{l}\text { The total power produced by the two } \\
\text { air turbines is reduced because the } \\
\text { inlet temperature for the second air } \\
\text { turbine is decreased. }\end{array}$ \\
\hline $\begin{array}{l}\text { P2G-ejector / } \\
\text { G2P-ejector }\end{array}$ & The air ejector is removed. & $\begin{array}{l}\text { When the operating pressure } \\
\text { exceeds } 45 \text { bar, the air temperature } \\
\text { from the compressor exceeds the } \\
\text { required SOC inlet temperature } \\
\left(600{ }^{\circ} \mathrm{C}\right)\end{array}$ & $\begin{array}{l}\text { The mass flow rate in the } \\
\text { turbomachinery increases } \\
\text { dramatically to cool down the SOC: } \\
\text { net power consumption of the air } \\
\text { side turbomachinery increases. }\end{array}$ \\
\hline $\begin{array}{l}\text { G2P- } \\
\text { recuperator }\end{array}$ & $\begin{array}{l}\text { The air recuperator (nodes } 33-34 \text { in } \\
\text { Figure B.1) is removed. }\end{array}$ & $\begin{array}{l}\text { When increasing the operating } \\
\text { pressure, the air temperature from } \\
\text { the compressor increases, at a } \\
\text { certain pressure the air does not } \\
\text { need to be preheated before going } \\
\text { to the ejector. }\end{array}$ & $\begin{array}{l}\text { The mass flow rate of air through the } \\
\text { compressor and the two air turbines } \\
\text { increases to cool the SOFC. Net } \\
\text { power consumption of the air side } \\
\text { turbomachinery increases. The RT } \\
\text { stack efficiency increases since the } \\
\mathrm{O}_{2} \text { content increases in the SOFC. }\end{array}$ \\
\hline
\end{tabular}




\subsubsection{Increasing the $\mathrm{H} / \mathrm{C}$ ratio}

The effects of increasing the $H / C$ ratio are analyzed in this section. The SOC inlet and operation temperatures, as well as the $U F_{S O F C}$, are kept constant. Depending on the SOC fuel electrode coking tolerance, the $H / C$ ratio will have to be increased above the minimum $\mathrm{H} / \mathrm{C}$ ratio. Figure 7 (a) shows the behavior of the operating pressure and efficiencies as $H / C$ increases from 6 to 7.5. The increase in $\mathrm{H} / \mathrm{C}$ ratio is obtained by adding more $\mathrm{H}_{2} \mathrm{O}$ through the humidifier in G2P mode and through humidifier and boiling water methanator in P2G. It is seen that the operating pressure increases with the $H / C$ ratio. The operation pressure is kept the same in both modes, and increases due to the catalytic recuperator in G2P mode. More precisely, the pressure increases to counterbalance the effect of the added $\mathrm{H}_{2} \mathrm{O}$ content in the catalytic recuperator, as a higher $\mathrm{H}_{2} \mathrm{O}$ content promotes reforming while a higher pressure represses reforming. Regarding carbon formation, both an increase in the operating pressure, and an increase in $H / C$ ratio, is beneficial to avoid carbon formation (see Figure 2(b)). The system RT efficiency is however negatively impacted by both the increase in pressure and the increase in $H / C$ ratio. Increasing the pressure beyond $\sim 20$ bar reduces the performance of the air turbomachinery as the outlet temperature of the air compressor gets close to the inlet temperature of the air turbine. The impact on the turbomachinery is stronger for the G2P mode because the mass flow through the air turbine is lower than the mass flow through the air compressor. The $P 2 G$ efficiency decreases slightly with increasing $H / C$ ratio due to the implementation of the $\mathrm{P} 2 \mathrm{G}-\mathrm{economizer}$ design change. Analogously, the necessity to implement the design change G2P-recuperator for the G2P mode above an $\mathrm{H} / \mathrm{C}$ ratio of 6.8 is detrimental for the performance at high pressures. The stack efficiency decreases over the range of $H / C$ ratio from 6 to 6.8 , due to the increase in the $\mathrm{H}_{2} \mathrm{O}$ content. Beyond an $H / C$ ratio of 6.8 where design change G2P-recuperator is implemented, the increase in $\mathrm{O}_{2}$ content and pressure results in an increased SOFC Nernst voltage and, consequently, an increase in stack RT efficiency.

As is clear from Figure $7(a)$, it does not seem to be optimal to have the same $H / C$ ratio in both operating modes. Instead the $H / C$ ratio can be higher in P2G mode than in G2P mode, to avoid carbon formation in the SOC in P2G mode. Carbon formation is not considered a potential problem in G2P mode if the carbon activity of the equilibrated inlet gas is below 1 .

Another parametric analysis is therefore made, in which the $H / C$ ratio of the G2P mode is kept constant at a low $H / C$ ratio while the $H / C$ ratio in $P 2 G$ mode is increased. The $H / C$ ratio in G2P mode is kept constant at 6.16, which is the highest value the system allows without implementing design changes. Because the $H / C$ ratio of the G2P mode is kept constant, the operating pressure will also be constant. Figure $7(\mathrm{~b})$ shows that increasing the $H / C$ ratio from 6.2 to 7.5 for the P2G mode, lowers the RT-efficiency by $0.6 \%$-points, whereas the RTefficiency was lowered by $2.3 \%$-points when the $H / C$ ratio was increased for both operating modes (Figure 7(a)). 


\subsubsection{Increasing the inlet temperature of the SOFC}

The second parametric analysis evaluates the effects of increasing the inlet temperature of the SOFC ${ }^{9}$, keeping constant the $H / C$ ratio at 6.06 for both modes ${ }^{10}$, the $U F_{S O F C}$ at 0.73 and the operating temperature of the $\mathrm{SOC}$ at $700{ }^{\circ} \mathrm{C}$. Increasing the inlet temperature of the SOFC decreases the temperature difference across the SOC thus lowering the thermomechanical stress in the SOC. The results of this parametric analysis are shown in Figure 7 (c). It can be seen that the pressure increases with the inlet temperature of the SOC. Similarly to the previous parametric analysis, the pressure increases due to the requirements of the catalytic recuperator used in the G2P mode. More precisely, the pressure increases to counterbalance the effect of the higher outlet temperature of the catalytic recuperator, as a higher outlet temperature promotes reforming while a higher pressure represses reforming. The system RT efficiency is significantly reduced, especially at high pressures due to the low efficiency of both operating modes. The main reason for the lower efficiency is the turbomachinery as described above for the previous parametric analysis. The effect is however even stronger because the pressure increases to 50 bar, whereas it only increased to 33 bar in the previous parametric analysis. The stack RT efficiency is stable until an inlet temperature of the SOFC of $610^{\circ} \mathrm{C}$. Beyond $610^{\circ} \mathrm{C}$, the design change G2P-recuperator is implemented and the related increase in stack RT efficiency has to be addressed to the increase of pressure and oxygen content in the SOFC.

\subsubsection{Changing the operating temperature of the SOC}

The last parametric analysis evaluates the effects of varying the operating temperature of the SOC. This is highly relevant, as state of the art SOC systems operate at $\sim 750^{\circ} \mathrm{C}[11,42]$. The operating temperature of the system is therefore varied from $650^{\circ} \mathrm{C}$ to $750^{\circ} \mathrm{C}[10-12]$. In this case, the $\mathrm{H} / \mathrm{C}$ ratio is set to the minimum value required to avoid carbon formation inside the SOC (Figure 2(b)). The UF in G2P mode is kept constant (0.73), as well as the temperature difference across the stack $\left(100^{\circ} \mathrm{C}\right)$. Figure $7(\mathrm{~d})$ shows the pressure behavior and the efficiencies as the operating temperature of the SOC is changed. The pressure increases with the operating temperature, because a higher inlet temperature of the stack is set. The pressure increase is however not as significant as in the second parametric analysis, mainly because the temperature difference across the stack is kept constant at $100{ }^{\circ} \mathrm{C}$, but also because the increasing pressure reduces the needed $H / C$ ratio - even though the temperature increases. The decrease in $H / C$ ratio decreases $S O C$ operation pressure as shown in the first parametric analysis. The system RT efficiency has a maximum of $79.6 \%$ at $680{ }^{\circ} \mathrm{C}$, but is almost constant from $650{ }^{\circ} \mathrm{C}$ to $710{ }^{\circ} \mathrm{C}$. This is because the $\mathrm{P} 2 \mathrm{G}$ mode has a maximum efficiency at $710^{\circ} \mathrm{C}$, while the efficiency of the G2P mode decreases with increasing temperature. That the G2P efficiency decreases with increasing pressure is as expected based on the previous two parametric analysis. The P2G efficiency increase from an operating temperature of $650^{\circ} \mathrm{C}$ to $710^{\circ} \mathrm{C}$ is attributed to the increase in air turbine power due to the increase in temperature and pressure. The drop in efficiency after $710^{\circ} \mathrm{C}$ is then due to a too high pressure, which was also seen in the previous two parametric

\footnotetext{
${ }^{9}$ The inlet temperature of the SOEC cannot be set. It is calculated by the adiabatic methanator upstream the SOC.

${ }^{10}$ This is the minimum $H / C$ ratio required at the given operating conditions. The $H / C$ ratio is slightly different from the base case because in this parametric analysis, the $H / C$ ratio is the same for both modes.
} 
analysis. The stack RT efficiency is stable around $80 \%$ as the effect of increasing the operating pressure is balanced by the increase in the operating temperature of the SOC.

(a)

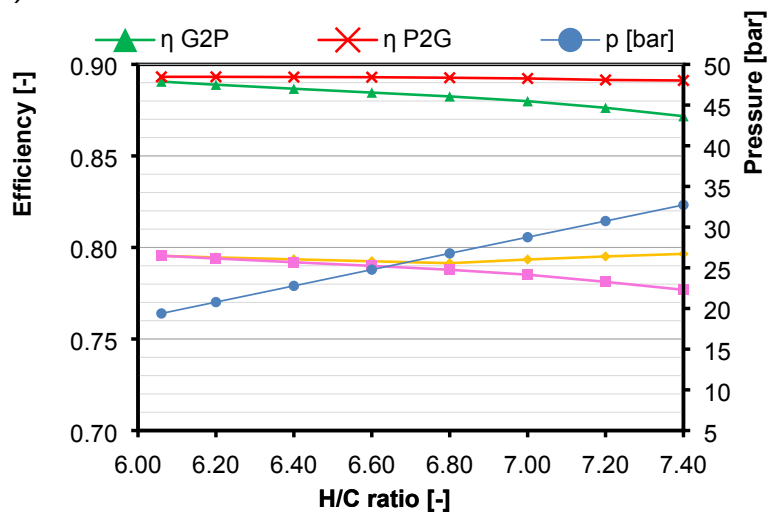

(c)

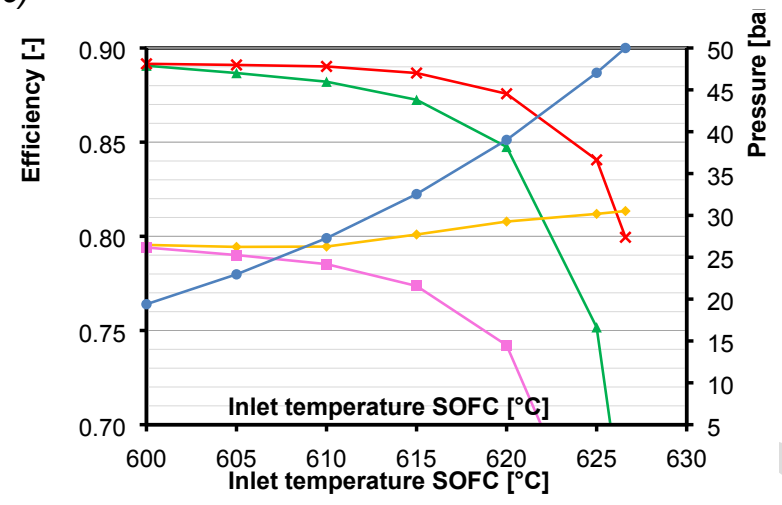

(b)

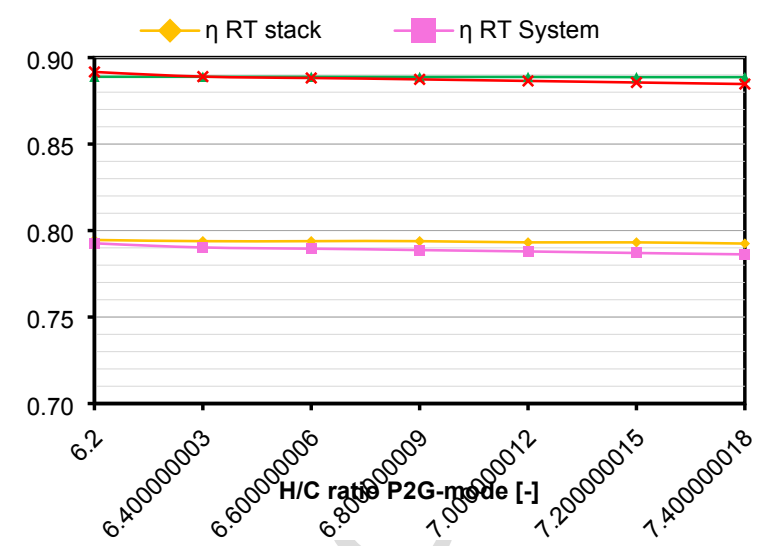

(d)

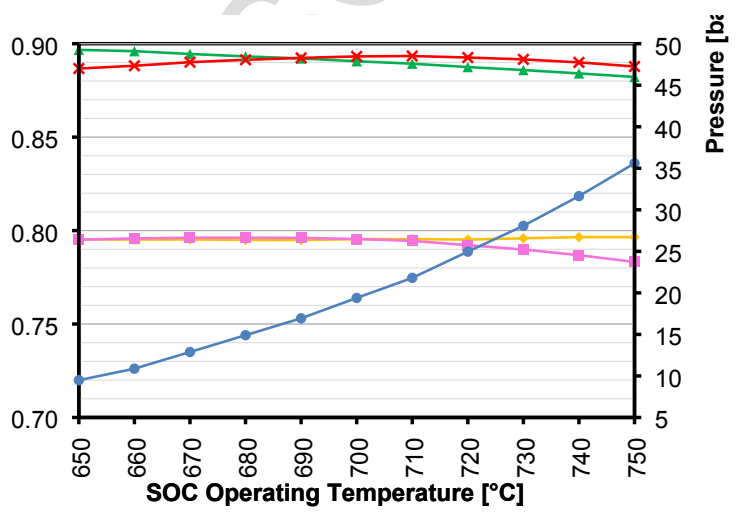

Figure 7: Efficiencies and operating pressure of the ES plant vs. :

(a) $H / C$ ratio in the SOC. The following design changes were made to enable the parameter variation: $P 2 G$-economizer from $H / C$ ratio of 6.2 to $7.4, G 2 P$-recuperator above an $H / C$ ratio of 6.8 .

(b) $H / C$ ratio in the SOEC. No design changes were made to enable the parameter variation. The H/C ratio of the G2P mode is kept constant at 6.16, corresponding to a constant pressure of 20.4 bar.

(c) inlet temperature of the SOFC. The following design changes were made to enable the parameter variation: $P 2 G-$ economizer above $T_{\text {in,SOFC }}=605^{\circ} \mathrm{C}, G 2 P$-recuperator above $T_{\text {in,SOFC }}=610^{\circ} \mathrm{C}$ and $P 2 G / G 2 P$-ejector above $T_{\text {in,SOFC }}=625^{\circ} \mathrm{C}$. (d) operating temperature of the $\mathrm{SOC}$. The $\mathrm{H} / \mathrm{C}$ ratio for each operating condition is set to the minimum $\mathrm{H} / \mathrm{C}$ needed to avoid carbon formation during electrolysis, according to Figure 2(b). The $\mathrm{H} / \mathrm{C}$ ratio is 6.19 at $650{ }^{\circ} \mathrm{C}$ and drops to 5.85 at $750{ }^{\circ} \mathrm{C}$. The following design changes were made to enable the parameter variation: P2G-economizer is used from $T_{\text {op }, \text { Soc }}=720^{\circ} \mathrm{C}$. Dots represents operating data calculated by DNA.

\subsubsection{Improving the SOC operating conditions}

Carbon formation and thermal stresses are two important issues for an SOC. It would therefore be beneficial for the SOC to increase the $H / C$ ratio and lower the temperature gradient in the SOC. The above parametric analysis showed a little decrease of the system performance when increasing the P2G H/C ratio, whereas the system RT efficiency dramatically decreased when increasing the inlet temperature to the SOC (keeping the outlet temperature fixed).

It is expected that operation in P2G mode with Ni-containing SOC fuel electrodes requires an $H / C$ ratio somewhat larger than the minimum $H / C$ ratio due to the higher gas diffusion coefficient for $\mathrm{H}_{2}$ relative to the coefficients for the other gas species which may cause a local decrease of the $H / C$ ratio at the electrode triple phase boundaries. Further kinetic limitations of the catalytic methanation reaction could affect the carbon formation threshold. A detailed modeling of this is beyond the scope of this paper. $H / C$ ratios of 7.5 and 6.2 have 
been chosen for P2G and G2P modes, respectively. This corresponds to the operating point from Figure $7(\mathrm{~b})$ at $H / C=7.5$. The key system parameters for this operating point are shown in Table 6 (case 1) and compared with the base case. The system RT efficiency is lowered from $79.6 \%$ to $78.9 \%$.

Further improvements in the operating conditions for the SOC can be obtained by decreasing the temperature difference across the stack. This can be achieved using an ejector on the fuel side of the SOC (Figure 8). The recirculation is calculated by DNA by setting the inlet temperature of the $\mathrm{SOC}$ to $650^{\circ} \mathrm{C}$, thus reducing the temperature difference across the stack from $100^{\circ} \mathrm{C}$ to $50^{\circ} \mathrm{C}$. For this case $2 \mathrm{a}$, an overall UF of the SOFC of 0.73 is set (between points $A$ and $C$ in Figure $8^{11}$ ), and the operating pressure is set to 20 bar. The system RT efficiency drops from $78.9 \%$ to $76.7 \%$, mainly due to an increased cell voltage in P2G caused by increased inlet Nernst voltage. However, this second solution ensures better operating conditions for the SOC. This also imply more uniform ASR along the gas channels in the SOC stack, as the ASR is highly temperature dependent. Consequently, a more uniform temperature inside the stack will help reaching the modeling assumption of an ASR of $0.2 \Omega \mathrm{cm}^{2}$. Therefore, the drop in RT efficiency will not be as significant as calculated here with constant ASR. Further, the stack UF for the P2G mode decreases from $93 \%$ (case 1 ) to $87 \%$, which is beneficial as a UF of $93 \%$ requires a very high fuel flow uniformity in the stack.

In addition, by using the ejector to increase the inlet fuel temperature, it is not necessary to have a temperature of $600^{\circ} \mathrm{C}$ at the outlet of the catalytic recuperator in SOFC mode. This means that the minimum temperature difference in the recuperator of $30{ }^{\circ} \mathrm{C}$ can be increased, thus lowering the heat transfer area and the cost of this component. By increasing the $\Delta T$ from $30^{\circ} \mathrm{C}$ to $60^{\circ} \mathrm{C}$ the RT efficiency drops from $76.7 \%$ to $76.4 \%$ (case $2 \mathrm{~b}$, Table 6 ). A techno-economic analysis would be needed to find the optimal solution.

Table 6: Key parameters for the cases investigated to improve the operating conditions of the SOC.

\begin{tabular}{|c|c|c|c|c|}
\hline & Base Case & Case 1 & Case $2 a$ & Case 2b \\
\hline Description & & $\begin{array}{l}\text { Higher } \mathrm{H} / \mathrm{C} \text { ratio in } \\
\mathrm{P} 2 \mathrm{G} \text { mode }\end{array}$ & $\begin{array}{l}\text { As case } 1 \text {, but with } \\
\text { fuel ejector }\end{array}$ & $\begin{array}{l}\text { As case } 2 \mathrm{a} \text {, but } \\
\text { higher } \Delta \mathrm{T} \text { in reformer }\end{array}$ \\
\hline \multicolumn{5}{|l|}{ Inputs } \\
\hline$H / C_{S O F C}$ & 5.99 & 6.16 & 6.2 & 6.2 \\
\hline$H / C_{S O E C}$ & 6.07 & 7.5 & 7.5 & 7.5 \\
\hline$\Delta T_{\text {min, recuperator }}\left[{ }^{\circ} \mathrm{C}\right]$ & 30 & 30 & 30 & 60 \\
\hline$\Delta T_{\text {SOC }}\left[{ }^{\circ} \mathrm{C}\right]$ & 100 & 100 & 50 & 50 \\
\hline$T_{\text {fuel-in,SOFC }}\left[{ }^{\circ} \mathrm{C}\right]$ & 600 & 600 & 650 & 650 \\
\hline$T_{f u e l-i n, S O E C}\left[{ }^{\circ} \mathrm{C}\right]$ & & - & 650 & 650 \\
\hline$T_{\text {air-in,SOFC/SOEC }}\left[{ }^{\circ} \mathrm{C}\right]$ & 600 & 600 & 650 & 650 \\
\hline$p_{\text {soc }}[\mathrm{bar}]$ & - & - & 20 & 20 \\
\hline UF & 0.73 & 0.73 & - & - \\
\hline \multicolumn{5}{|l|}{ Results } \\
\hline$\eta_{G 2 P}[\%]$ & 89.1 & 88.9 & 88.1 & 87.7 \\
\hline$\eta_{P 2 G}[\%]$ & 89.3 & 88.7 & 87.1 & 87.1 \\
\hline$\eta_{R T}[\%]$ & 79.6 & 78.9 & 76.7 & 76.4 \\
\hline$p_{\text {SOC }}[\mathrm{bar}]$ & 18.7 & 20.4 & - & - \\
\hline$T_{\text {fuel-in, SOEC }}\left[{ }^{\circ} \mathrm{C}\right]$ & 604 & 597 & - & - \\
\hline$T_{\text {eq,fuel-in, SOEC }}{ }^{*}\left[{ }^{\circ} \mathrm{C}\right]$ & 604 & 597 & 655 & 655 \\
\hline$T_{\text {eq,fuel-in,SOFC }}{ }^{\circ}\left[{ }^{\circ} \mathrm{C}\right]$ & 600 & 600 & 622 & 620 \\
\hline
\end{tabular}

${ }^{11}$ The stack UF (from point $B$ to point $C$ in Figure 8) decreased because of the recycle with the ejector on the fuel side. 


\begin{tabular}{lllll}
$U F_{S O F C}$ & - & - & 0.62 & 0.59 \\
$U F_{S O E C}$ & 0.93 & 0.94 & 0.87 & 0.87 \\
$R_{S O F C} R^{a}$ & - & - & 0.41 & 0.48 \\
$R_{\text {SOEC }}$ & - & - & 0.55 & 0.55 \\
\hline
\end{tabular}

* This is the equilibrium temperature of the inlet fuel gas to the SOC. It is noted that the equilibrium temperature is higher than the actual fuel inlet temperature in SOFC mode, and vice versa for SOEC mode.

a The recirculation ratio $R R$ is defined as the mass flow rate of fuel recycled with respect to the total mass flow rate of fuel exiting the SOC.

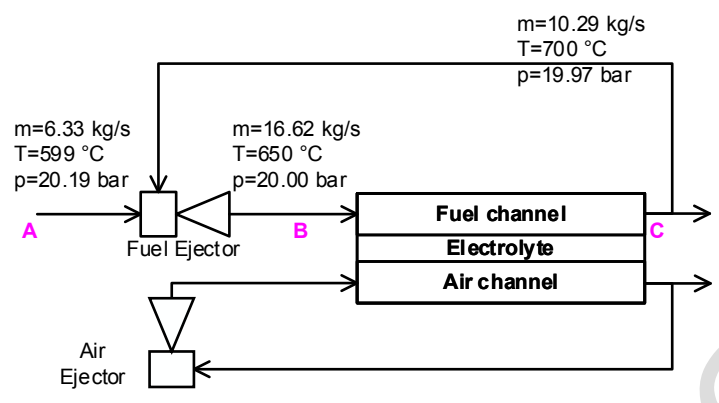

Figure 8: SOC with air and fuel ejector. Mass flow rates, pressures and temperatures refer to the G2P mode of case 2a in Table 6.

\section{Discussion}

The calculations performed using DNA showed that the ES system can reach a stack RT efficiency of $\sim 80 \%$ with a fuel utilization factor (UF) of 0.73 . Wendel et al. [16] and Jensen et al. [17] presented an ES plant with a stack RT efficiency around $76 \%$, considering the same UF of 0.73 , but an operating temperature of $650^{\circ} \mathrm{C}$. The increase in the stack RT efficiency is attributed to the reduced current density used in the SOC $\left(0.5 \mathrm{~A} / \mathrm{cm}^{2}\right.$ vs. 0.7 $\mathrm{A} / \mathrm{cm}^{2}$ ), but also to the increased stack methane formation in electrolysis mode, and to the increased stack steam reforming in fuel cell mode. This is achieved because the inlet gas to the SOC is at equilibrium $100{ }^{\circ} \mathrm{C}$ below the SOC operating temperature. The reduction in the current density is possible due to the improved thermal integration (use of humidifiercondenser loop) and the use of the cooled methanation reactor, which makes the overall P2G operation more exothermic, thus allowing a lower heat production within the SOEC. Accordingly the overall plant RT efficiency improves.

It is observed that the system design presented in this paper achieves the same stack and plant RT efficiency $(\sim 80 \%)$, whereas the plant RT efficiency in the previous studies $[16,17]$ was lower $(74 \%)$ than the stack RT efficiency $(76 \%)$. The reason why the presented system design features similar stack and plant RT efficiencies relates to the BOP hardware which positively affects the plant conversion efficiency in P2G mode. In G2P mode, the BOP components affect the system efficiency negatively. This was not the case in the previous studies $[16,17]$, where the BOP hardware influenced negatively the plant efficiency in P2G mode, while the effect in G2P mode depended on the UF ${ }^{12}$. The modelling study revealed that it was possible to raise the SOC operating temperature from $650{ }^{\circ} \mathrm{C}$ assumed in previous studies $[16,17]$ to $700{ }^{\circ} \mathrm{C}$ without having to increase the pressure. There was however a strong correlation between operating temperature and pressure in the new ES plant, meaning that if the operating temperature was reduced from $700{ }^{\circ} \mathrm{C}$ to $650{ }^{\circ} \mathrm{C}$, the pressure would decrease from 18.7 bar to 9.5 bar. The plant RT efficiency would essentially

\footnotetext{
${ }^{12}$ At the same UF of 0.73 the BOP had a negative effect (net power consumption). At an UF of 0.9 the BOP produced net power [16].
} 
not be affected as it decreases from $79.6 \%$ to $79.5 \%$. Furthermore, it was shown that the operating temperature could be increased to $750{ }^{\circ} \mathrm{C}$ with only a slight decrease in RT efficiency $(78.2 \%)$. The operating pressure would in this case increase to $\sim 35$ bar.

The content of $\mathrm{CH}_{4}$ in the stored SNG is $97.2 \mathrm{~mol} \%$, which is high enough for injection in the current NG network ${ }^{13}$. The $\mathrm{CH}_{4}$ fraction in the stored fuel is higher than what has been achieved in the previous studies about the ES system [15-18]. The novel ES system could avoid the use of a storage tank or cavern for the generated fuel, and instead inject the SNG in the NG pipeline. In G2P mode, the starting fuel would hence be withdrawn from the NG grid. This result has high impact both on the flexibility and on the economic feasibility of the plant. The novel ES plant, previously constrained by the storage tanks, can now operate considering the electricity and NG markets. Seen from a system operator point of view the ES system can act as an efficient and strong link between the electricity and gas markets. Avoiding a dedicated fuel storage tank or cavern translates into a lower capital cost of the overall plant. The cost of the gas storage has a significant impact on the total cost of the plant [17]. The total plant cost is expected to be similar to the one reported in [17] for a similar system without catalytic reactors ( $269 \mathrm{M} \$$ for a system with a $250 \mathrm{MW}$ SOC), as the fuel storage cavern is avoided.

The ES system storage capacity is limited by the $\mathrm{CO}_{2}$-rich gas storage when operating in P2G mode ${ }^{14}$, but could continue to operate in G2P mode even after the $\mathrm{CO}_{2}$ storage was full. In such a case, it would make sense to increase the fuel utilization of the SOFC from 0.73 to e.g. 0.9 and combust the residual combustible gasses and then expand them in a gas turbine to maximize the electric power output. Preliminary modeling results suggest that the power output in G2P mode could be doubled in this way.

The $\mathrm{CO}$ content of $\sim 9 \mathrm{~mol} \%$ in the $\mathrm{CO}_{2}$-rich gas storage could be a safety concern, but could be reduced by implementing a single low-temperature adiabatic water-gas shift reactor before the condenser at $185^{\circ} \mathrm{C}$ in G2P mode. In this way the $\mathrm{CO}$ content could be reduced by a factor of $\sim 50$ to a $\mathrm{CO}$ content of $\sim 0.2 \mathrm{~mol} \%$ in the stored gas, while the RT efficiency only drops by $\sim 0.6 \%$-point. Because of the low $\mathrm{CO}$ content, the outlet temperature of the adiabatic methanator (preheating the fuel gas before the SOEC) drops from $604{ }^{\circ} \mathrm{C}$ to 591 ${ }^{\circ} \mathrm{C}$. This means a fuel ejector or heat exchanger most likely should be implemented to raise the inlet temperature to the SOEC.

Concerning possible improvements to the system, as shown in section 4.4.4, the use of the ejector on the fuel side ensures better operating conditions for the SOC (lower inlet/outlet temperature difference and lower utilization factors) without sacrificing the system RT efficiency. This means that state of the art solid oxide cells could be used in the system, if they are proven to be operable at elevated pressures.

\footnotetext{
${ }^{13}$ Future grid requirements may allow $\sim 15 \% \mathrm{H}_{2}$ [43].

${ }^{14} \mathrm{The} \mathrm{CO}_{2}$-rich gas occupies $\sim 4,830 \mathrm{~m}^{3}\left(\sim 600,000 \mathrm{Nm}^{3}\right)$ of storage volume per day of operation in $\mathrm{G} 2 \mathrm{P}$ mode. For comparison, the average capacity of the 163 underground natural gas storages in EU is 1 billion $\mathrm{Nm}^{3}$ [9].

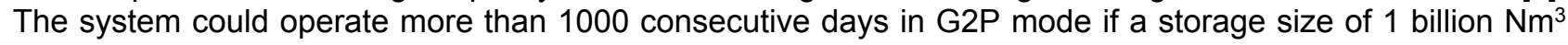
were used.
} 


\subsection{Combining ES and SNG production from syngas or biogas}

The ES system capacity factor is important for the system economy [17]. To maximize the capacity factor, the ES system could be combined with biogas or bio-syngas upgrading. Biogas or bio-syngas could be added in both modes of operation. In G2P mode the biogas/syngas would be mixed with SNG and converted to electricity in the SOFC. In P2G mode the biogas/syngas would be mixed with the $\mathrm{CO}_{2}$-rich gas, or sent directly to the cooled methanator. $\mathrm{H}_{2}$ and $\mathrm{CO}$ in bio-syngas could eliminate the need for the catalytic recuperator (needed in SOFC mode) as the gas mixture would resemble pre-reformed natural gas.

At intermediate electricity prices it may be economically infeasible to only store or produce electricity, but upgrading of syngas or biogas could keep the plant operating in SOEC mode at part load because of the income generated from SNG production.

\section{Conclusion}

In this paper we present the modeling results for a highly efficient electricity storage system. The system is based on pressurized solid oxide cells (SOCs). Combined with catalytic reactors the system can reversibly convert electricity and a $\mathrm{CO}_{2}$ rich gas into synthetic natural gas (SNG). Compared to previous systems proposed for large-scale electricity storage, the presented analysis shows possibilities for an exceptionally high round-trip (RT) efficiency (electricity-to-gas-to-electricity) of up to $80 \%$.

During electricity storage, $\mathrm{CO}_{2}$ and $\mathrm{H}_{2} \mathrm{O}$ is converted to $\mathrm{CO}$ and $\mathrm{H}_{2}$ inside the SOCs. The cells are operated at elevated pressure enabling most of the $\mathrm{CO}$ and $\mathrm{H}_{2}$ to be converted to $\mathrm{CH}_{4}$ inside the cell. The process is reversed during electricity production. The internal $\mathrm{CH}_{4}$ conversion is crucial for a high RT efficiency. The optimized interplay between the catalytic reactors and the additional balance of plant (BOP) components, enables efficient operation and an almost full conversion to $\mathrm{CH}_{4}$ of the remaining $\mathrm{CO}$ and $\mathrm{H}_{2}$ in the $\mathrm{SOC}$ outlet gas. Importantly, during electricity storage the system produces a gas containing $\sim 97 \% \mathrm{CH}_{4}$ enabling direct injection into existing natural gas grids and usage in existing SNG infrastructures.

For optimum conversion efficiency the system requires SOC stack operation around 20 bar. The SOC stack operation concept was recently demonstrated with a 30-cell stack from SOFCMAN operated at 19 bar. $18 \% \mathrm{CH}_{4}$ was formed inside the stack during electricity storage operation. The reverse operation was also demonstrated with conversion of $\mathrm{CH}_{4}$ to $\mathrm{CO}_{2}$ and $\mathrm{H}_{2} \mathrm{O}$ inside the stack.

Cost efficient storage of the $\mathrm{CO}_{2}$ rich gas is required for the system to operate. Subsurface $\mathrm{CO}_{2}$ storage could become attractive, much similar to today's subsurface NG storage. Large-scale subsurface $\mathrm{CO}_{2}$ storage is already a mature technology used for EOR, and it is projected and tested for carbon CCS.

In addition to electricity storage, the ES system may be configured to combine electricity storage with upgrading of syngas or biogas to SNG. This may increase the capacity factor beyond what can be achieved with electricity arbitrage (i.e. reducing the idling time at 
periods with intermediate electricity prices) and thus improve the commercial viability of the system.

In summary, the proposed ES system can potentially provide a strong and efficient link between the electricity and the natural gas markets. The high RT efficiency and potentially low storage costs could facilitate major additional deployment of intermittent solar and wind power in our existing energy infrastructures.

\section{Conflicts of interest}

There are no conflicts of interest to declare.

\section{Acknowledgements}

The authors wish to thank for financial funding from the Energy Technology Development and Demonstration Program (EUDP) at the Danish Energy Agency via "Maturing SOEC", project no. 64015-0523.

\section{Notes and references}

[1] Bonn climate change conference (COP 23) | Climate Action n.d.

https://ec.europa.eu/clima/events/articles/0118_en (accessed August 24, 2018).

[2] Paris Agreement | Climate Action n.d.

https://ec.europa.eu/clima/policies/international/negotiations/paris_en (accessed August 24, 2018).

[3] Dodoo A, Gustavsson L, Sathre R. Life cycle primary energy implication of retrofitting a wood-framed apartment building to passive house standard. Resour, Conserv Recycl 2010;54:1152-60.

doi:10.1016/j.resconrec.2010.03.010.

[4] The climate initiative in Denmark n.d. https://en.efkm.dk/climate-and-weather/the-climate-initiative-indenmark/ (accessed August 24, 2018).

[5] Danish climate policies | Energistyrelsen n.d. https://ens.dk/en/our-responsibilities/energy-climatepolitics/danish-climate-policies (accessed August 24, 2018).

[6] Leung DYC, Caramanna G, Maroto-Valer MM. An overview of current status of carbon dioxide capture and storage technologies. Renewable Sustainable Energy Rev 2014;39:426-43. doi:10.1016/j.rser.2014.07.093.

[7] Kuuskraa VA, Godec ML, Dipietro P. CO2utilization from "next generation" CO2enhanced oil recovery technology. Energy Procedia 2013;37:6854-66. doi:10.1016/j.egypro.2013.06.618.

[8] Li L, Khorsandi S, Johns RT, Dilmore RM. CO2enhanced oil recovery and storage using a gravityenhanced process. Int J Greenhouse Gas Control 2015;42:502-15. doi:10.1016/j.ijggc.2015.09.006.

[9] Storage Map | GIE n.d. https://www.gie.eu/index.php/gie-publications/maps-data/gse-storage-map (accessed August 24, 2018).

[10] Elcogen n.d. http://www.elcogen.com/\#intro (accessed August 24, 2018).

[11] Noponen M, Temmo A, Koit A, Torri P, Göös J. A0807 Status of Elcogen unit cell and stack development. 11th Eur. SOFC SOE Forum, Lucerne: 2014, p. 92-6.

[12] Noponen M, Torri P, Goos J, Chade D, Hallanoro P, Temmo A, et al. Status of Solid Oxide Fuel Cell Development at Elcogen. ECS Trans 2015;68:151-6. doi:10.1149/06801.0151ecst.

[13] Produce your own carbon monoxide | Haldor Topsoe n.d. https://www.topsoe.com/processes/carbonmonoxide/site-carbon-monoxide (accessed August 24, 2018).

[14] Jensen SH, Sun X, Ebbesen SD, Chen M. Pressurized Operation of a Planar Solid Oxide Cell Stack. Fuel Cells 2016;16:205-18. doi:10.1002/fuce.201500180.

[15] Wendel $\mathrm{CH}$, Braun RJ. Design and techno-economic analysis of high efficiency reversible solid oxide cell systems for distributed energy storage. Appl Energy 2016;172:118-31. doi:10.1016/j.apenergy.2016.03.054.

[16] Wendel $\mathrm{CH}$, Kazempoor P, Braun RJ. Novel electrical energy storage system based on reversible solid oxide cells: System design and operating conditions. J Power Sources 2015;276:133-44. doi:10.1016/j.jpowsour.2014.10.205.

[17] Jensen SH, Graves C, Mogensen M, Wendel C, Braun RJ, Hughes G, et al. Large-scale electricity storage utilizing reversible solid oxide cells combined with underground storage of $\mathrm{CO} 2$ and $\mathrm{CH} 4$. Energy Environ Sci 2015;8:2471-9. doi:10.1039/C5EE01485A.

[18] Monti A, Wendel CH, Santarelli M, Braun RJ. Energy Dense Storage Using Intermediate Temperature Reversible Solid Oxide Cells. ECS Trans 2015;68:3289-300. doi:10.1149/06801.3289ecst. 
[19] Giglio E, Lanzini A, Santarelli M, Leone P. Synthetic natural gas via integrated high-temperature electrolysis and methanation: Part I-Energy performance. Journal of Energy Storage 2015;1:22-37. doi:10.1016/j.est.2015.06.004.

[20] Giglio E, Lanzini A, Santarelli M, Leone P. Synthetic natural gas via integrated high-temperature electrolysis and methanation: Part II-Economic analysis. Journal of Energy Storage 2015;2:64-79. doi:10.1016/j.est.2015.06.004.

[21] Luo Y, Shi Y, Li W, Cai N. Synchronous enhancement of $\mathrm{H} 2 \mathrm{O} / \mathrm{CO} 2 \mathrm{co}-$ electrolysis and methanation for efficient one-step power-to-methane. Energy Convers Manag 2018;165:127-36. doi:10.1016/j.enconman.2018.03.028.

[22] Luo Y, Wu X yu, Shi Y, Ghoniem AF, Cai N. Exergy analysis of an integrated solid oxide electrolysis cell-methanation reactor for renewable energy storage. Appl Energy 2018;215:371-83. doi:10.1016/j.apenergy.2018.02.022.

[23] Ebbehøj SL. Integration of $\mathrm{CO} 2$ air capture and solid oxide electrolysis for methane production. Technical University of Denmark, 2015.

[24] Kazempoor P, Braun RJ. Model validation and performance analysis of regenerative solid oxide cells for energy storage applications: Reversible operation. Int J Hydrogen Energy 2014;39:5955-71. doi:10.1016/j.ijhydene.2014.01.186.

[25] Kazempoor P, Braun RJ. Model validation and performance analysis of regenerative solid oxide cells: Electrolytic operation. Int J Hydrogen Energy 2014;39:2669-84. doi:10.1016/j.ijhydene.2013.12.010.

[26] Rostrup-Nielsen JR, Bak Hansen JH. CO2-reforming of methane over transition metals. J Catal 1993;144:38-49. doi:10.1006/jcat.1993.1312.

[27] Mills GA, Steffgen FW. Catalytic methanation. Catal Rev 1974;8:159-210. doi:10.1080/01614947408071860.

[28] Jensen SH, Langnickel H, Hintzen N, Chen M, Hauch A, Butera G, et al. PRESSURIZED REVERSIBLE OPERATION OF A 30-CELL SOLID OXIDE CELL STACK USING CARBONACEOUS GASSES. Eur. Fuel Cell Technol. Appl. Conf. - Piero Lunghi Conf., Naples: 2017.

[29] Bierschenk DM, Wilson JR, Barnett SA. High efficiency electrical energy storage using a methaneoxygen solid oxide cell. Energy Environ Sci 2011;4:944-51. doi:10.1039/C0EE00457J.

[30] Elmegaard B. Development, Evaluation and Application of a General Energy System Simulation Tool. Technical University of Denmark, 1999.

[31] Elmegaard B. DNA - A general energy system simulation tool. SIMS 2005, 46th Conf. Simul. Model., 2005, p. 43-52.

[32] Facchinetti E. Integrated Solid Oxide Fuel Cell - Gas Turbine Hybrid Systems with or without CO2 Separation. 2012.

[33] Bejan A. Advanced Engineering Thermodynamics. THIRD EDIT. n.d.

[34] Stoots CM, O'Brien JE, Herring JS, Hartvigsen JJ. Syngas Production via High-Temperature Coelectrolysis of Steam and Carbon Dioxide. J Fuel Cell Sci Technol 2009;6:011014. doi:10.1115/1.2971061.

[35] Ebbesen SD, Knibbe R, Mogensen M. Co-Electrolysis of Steam and Carbon Dioxide in Solid Oxide Cells. J Electrochem Soc 2012;159:F482-9. doi:10.1149/2.076208jes.

[36] Kim-Lohsoontorn P, Bae J. Electrochemical performance of solid oxide electrolysis cell electrodes under high-temperature coelectrolysis of steam and carbon dioxide. J Power Sources 2011;196:7161-8. doi:10.1016/j.jpowsour.2010.09.018.

[37] Hohmeyer O, Trittin T, editors. IPCC SCOPING MEETING ON RENEWABLE ENERGY SOURCES, Lübeck, Germany: 2008.

[38] Naturgasnettet i Danmark - Naturgasfakta n.d. http://www.naturgasfakta.dk/copy_of_miljoekrav-tilenergianlaeg/naturgasnettet-i-danmark (accessed August 24, 2018).

[39] Gas Quality in Denmark | Energinet n.d. https://en.energinet.dk/Gas/Gas-Quality (accessed August 24, 2018).

[40] Jensen SH, Graves C, Chen M, Hansen JB, Sun X. Characterization of a Planar Solid Oxide Cell Stack Operated at Elevated Pressure. J Electrochem Soc 2016;163:F1596-604. doi:10.1149/2.1171614jes.

[41] Wang G, Konstantinou G, Townsend CD, Pou J, Vazquez S, Demetriades GD, et al. A review of power electronics for grid connection of utility-scale battery energy storage systems. IEEE Trans Sustain Energy 2016;7:1778-90. doi:10.1109/TSTE.2016.2586941.

[42] Blum L, Packbier U, Vinke IC, De Haart LGJ. Long-term testing of SOFC stacks at forschungszentrum jülich. Fuel Cells 2013;13:646-53. doi:10.1002/fuce.201200151.

[43] Melaina MW, Antonia O, Penev M. Blending Hydrogen into Natural Gas Pipeline Networks : A Review of Key Issues Blending Hydrogen into Natural Gas Pipeline Networks : A Review of Key Issues 2013:131. doi:10.2172/1068610. 
Appendix A: P2G mode (Detailed ES system) 


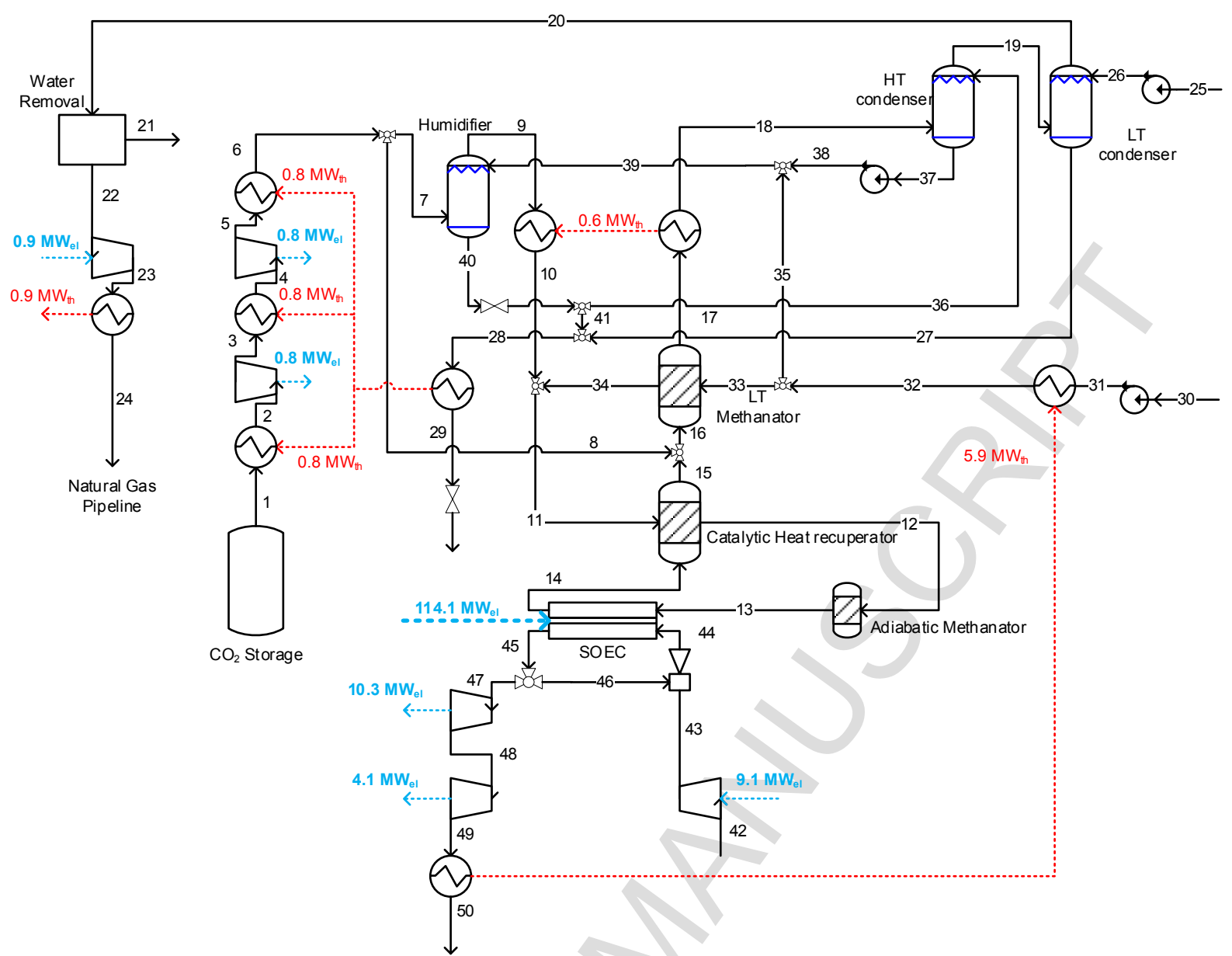

Figure A.1: Detailed plant for P2G mode. If transferred heat is not shown, the corresponding value is presented in Table A. 4 below.

Table A.1: Mass flow rates and thermodynamic properties for the streams in the novel ES plant. Nodes refer to Figure A.1.

\begin{tabular}{lrrr|lrrr|lrrr}
\hline Node & $\mathrm{m}[\mathrm{kg} / \mathrm{s}]$ & $\mathrm{T}\left[{ }^{\circ} \mathrm{C}\right]$ & $\mathrm{p}[\mathrm{b} a r]$ & Node & $\mathrm{m}[\mathrm{kg} / \mathrm{s}]$ & $\mathrm{T}\left[{ }^{\circ} \mathrm{C}\right]$ & $\mathrm{p}[\mathrm{bar}]$ & Node & $\mathrm{m}[\mathrm{kg} / \mathrm{s}]$ & $\mathrm{T}\left[{ }^{\circ} \mathrm{C}\right]$ & $\mathrm{p}[\mathrm{bar}]$ \\
\hline 1 & 7.35 & 35 & 140.0 & 18 & 4.66 & 227 & 18.67 & 35 & 3.53 & 209 & 18.70 \\
2 & 7.35 & 115 & 140.0 & 19 & 3.51 & 134 & 18.67 & 36 & 27.30 & 128 & 18.67 \\
3 & 7.35 & 37 & 50.00 & 20 & 2.88 & 30 & 18.67 & 37 & 28.45 & 157 & 18.67 \\
4 & 7.35 & 115 & 50.00 & 21 & 0.01 & 30 & 18.67 & 38 & 28.45 & 157 & 18.70 \\
5 & 7.35 & 40 & 18.70 & 22 & 2.88 & 30 & 18.67 & 39 & 31.98 & 163 & 18.70 \\
6 & 7.35 & 115 & 18.70 & 23 & 2.88 & 157 & 80.00 & 40 & 29.99 & 128 & 18.70 \\
7 & 5.81 & 115 & 18.70 & 24 & 2.88 & 30 & 80.00 & 41 & 2.69 & 128 & 18.67 \\
8 & 1.53 & 115 & 18.70 & 25 & 4.62 & 20 & 1.01 & 42 & 20.07 & 25 & 1.00 \\
9 & 7.80 & 158 & 18.70 & 26 & 4.62 & 20 & 18.67 & 43 & 20.07 & 454 & 18.98 \\
10 & 7.80 & 209 & 18.70 & 27 & 5.25 & 129 & 18.67 & 44 & 49.03 & 600 & 18.70 \\
11 & 11.42 & 209 & 18.70 & 28 & 7.95 & 129 & 18.67 & 45 & 57.32 & 700 & 18.67 \\
12 & 11.42 & 483 & 18.70 & 29 & 7.95 & 57 & 18.67 & 46 & 28.96 & 700 & 18.67 \\
13 & 11.42 & 604 & 18.70 & 30 & 7.15 & 20 & 1.01 & 47 & 28.36 & 700 & 18.67 \\
14 & 3.13 & 700 & 18.67 & 31 & 7.15 & 20 & 18.70 & 48 & 28.36 & 372 & 3.00 \\
15 & 3.13 & 241 & 18.67 & 32 & 7.15 & 209 & 18.70 & 49 & 28.36 & 234 & 1.10 \\
16 & 4.66 & 220 & 18.67 & 33 & 3.62 & 209 & 18.70 & 50 & 28.36 & 30 & 1.10 \\
17 & 4.66 & 280 & 18.67 & 34 & 3.62 & 209 & 18.70 & & & & \\
\hline
\end{tabular}

Table A.2: Molar composition of the main flows for the $P 2 G$ mode. Nodes refer to Figure A.1.

\begin{tabular}{rrrrrr}
\hline Nodes & $\mathrm{H}_{2}$ & $\mathrm{CO}$ & $\mathrm{CO}_{2}$ & $\mathrm{H}_{2} \mathrm{O}$ & $\mathrm{CH}_{4}$ \\
\hline $1-8$ & 0.416 & 0.094 & 0.461 & 0.000 & 0.029 \\
$9-10$ & 0.285 & 0.064 & 0.315 & 0.316 & 0.020 \\
\hline
\end{tabular}




\begin{tabular}{rrrrrr}
\hline $11-12$ & 0.182 & 0.041 & 0.202 & 0.562 & 0.013 \\
13 & 0.128 & 0.017 & 0.214 & 0.605 & 0.094 \\
$14-15$ & 0.434 & 0.018 & 0.006 & 0.078 & 0.448 \\
16 & 0.431 & 0.031 & 0.084 & 0.351 & 0.376 \\
$17-18$ & 0.014 & $\sim 0$ & 0.004 & 0.158 & 0.631 \\
19 & 0.019 & $\sim 0$ & 0.005 & 0.002 & 0.819 \\
20 & 0.022 & $\sim 0$ & 0.006 & 0 & 0.970 \\
$22-24$ & 0.022 & $\sim 0$ & 0.006 & 0.972 \\
$21,25-41$ & 0 & 0 & 0 & 0 & 0 \\
\hline
\end{tabular}

Table A.3: Molar composition of the flows on the air side for the P2G mode. Nodes refer to Figure A.1.

\begin{tabular}{rrr}
\hline Nodes & $\mathrm{O}_{2}$ & $\mathrm{~N}_{2}$ \\
\hline $42-43$ & 0.210 & 0.790 \\
$45-50$ & 0.422 & 0.578 \\
44 & 0.334 & 0.667 \\
\hline
\end{tabular}

Table A.4: Heat transferred in the different components in G2P mode. Components refer to Figure A.1.

\begin{tabular}{lr}
\hline Component & Heat transferred [kW] \\
\hline Catalytic Recuperator & 6.0 \\
LT Methanator & 6.9 \\
Humidifier & 4.6 \\
HT Condenser & 3.5 \\
LT Condenser & 2.1 \\
\hline
\end{tabular}

Appendix B: G2P mode (Detailed ES) 


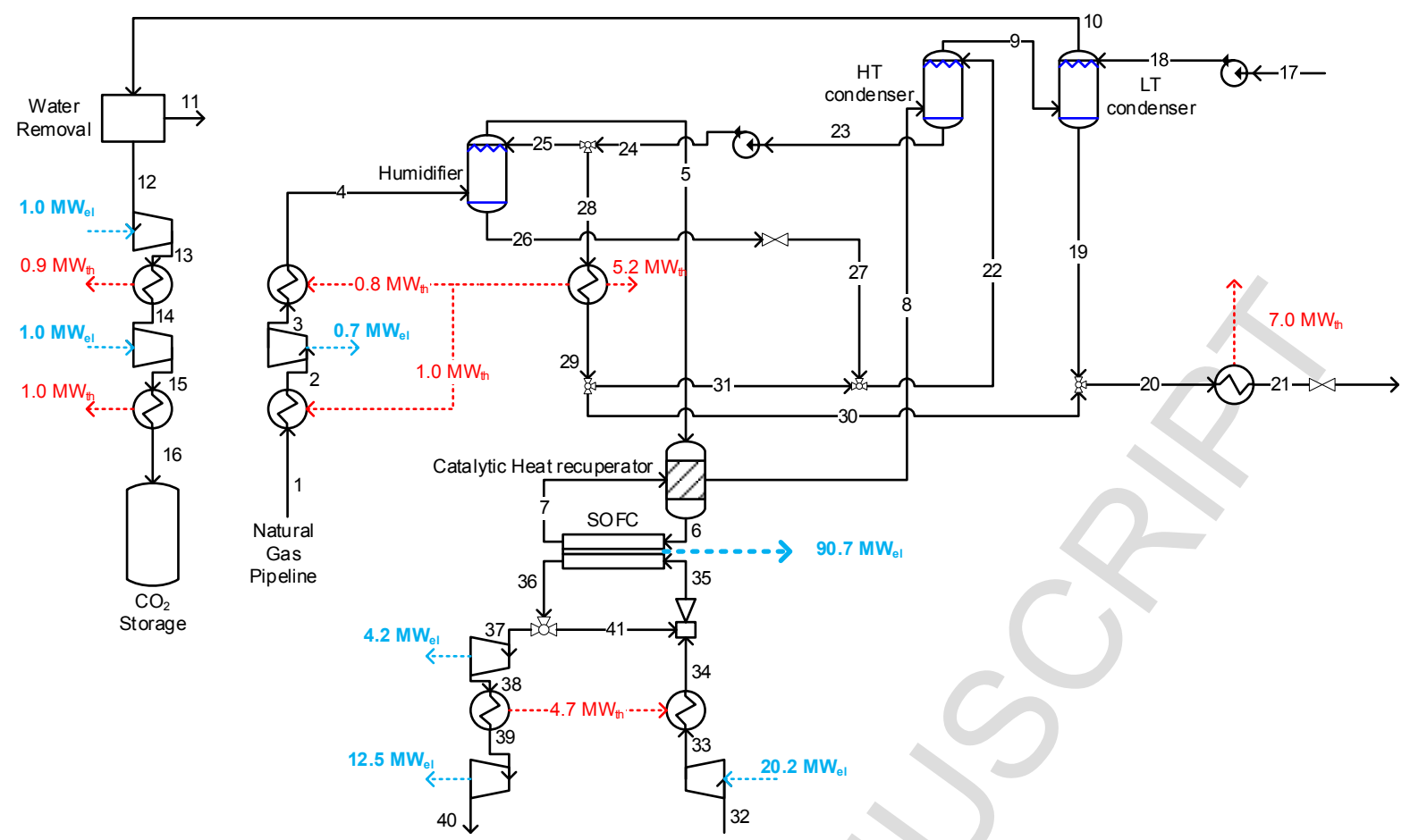

Figure B.1: Detailed plant for G2P mode. If transferred heat is not shown, the corresponding value is presented in

Table B. 4 below.

Table B.1: Mass flow rates and thermodynamic properties for the novel ES plant in G2P mode. Nodes refer to Figure B.1.

\begin{tabular}{|c|c|c|c|c|c|c|c|c|c|c|c|}
\hline Node & $\mathrm{m}[\mathrm{kg} / \mathrm{s}]$ & $\mathrm{T}\left[{ }^{\circ} \mathrm{C}\right]$ & $\mathrm{p}$ [bar] & Node & $\mathrm{m}[\mathrm{kg} / \mathrm{s}]$ & $\mathrm{T}\left[{ }^{\circ} \mathrm{C}\right]$ & $\mathrm{p}$ [bar] & Node & $\mathrm{m}[\mathrm{kg} / \mathrm{s}]$ & $\mathrm{T}\left[{ }^{\circ} \mathrm{C}\right]$ & $\mathrm{p}$ [bar] \\
\hline 1 & 2.88 & 30 & 80.00 & 15 & 7.35 & 128 & 140.00 & 29 & 43.97 & 145 & 18.67 \\
\hline 2 & 2.88 & 170 & 80.00 & 16 & 7.35 & 35 & 140.00 & 30 & 1.97 & 145 & 18.67 \\
\hline 3 & 2.88 & 66 & 18.70 & 17 & 10.10 & 20 & 1.01 & 31 & 42.00 & 145 & 18.67 \\
\hline 4 & 2.88 & 170 & 18.70 & 18 & 10.10 & 20 & 18.67 & 32 & 44.38 & 25 & 1.00 \\
\hline 5 & 6.01 & 176 & 18.70 & 19 & 11.95 & 145 & 18.67 & 33 & 44.38 & 452 & 18.79 \\
\hline 6 & 6.01 & 600 & 18.70 & 20 & 13.92 & 145 & 18.67 & 34 & 44.38 & 548 & 18.79 \\
\hline 7 & 14.30 & 700 & 18.67 & 21 & 13.92 & 25 & 18.67 & 35 & 66.99 & 600 & 18.70 \\
\hline 8 & 14.30 & 267 & 18.67 & 22 & 83.24 & 145 & 18.67 & 36 & 58.70 & 700 & 18.67 \\
\hline 9 & 9.20 & 150 & 18.67 & 23 & 88.35 & 181 & 18.67 & 37 & 36.09 & 700 & 18.67 \\
\hline 10 & 7.35 & 25 & 18.67 & 24 & 88.35 & 181 & 18.70 & 38 & 36.09 & 597 & 11.51 \\
\hline 11 & 0.01 & 25 & 18.67 & 25 & 44.37 & 181 & 18.70 & 39 & 36.09 & 482 & 11.51 \\
\hline 12 & 7.35 & 25 & 18.67 & 26 & 41.23 & 145 & 18.70 & 40 & 36.09 & 158 & 1.10 \\
\hline 13 & 7.35 & 118 & 50.00 & 27 & 41.23 & 145 & 18.67 & 41 & 22.61 & 700 & 18.67 \\
\hline 14 & 7.35 & 30 & 50.00 & 28 & 43.98 & 181 & 18.70 & & & & \\
\hline
\end{tabular}

Table B.2: Molar composition of the main flows for the G2P mode. Nodes refer to Figure Figure B.1.

\begin{tabular}{rrrrrr}
\hline Nodes & $\mathrm{H}_{2}$ & $\mathrm{CO}$ & $\mathrm{CO}_{2}$ & $\mathrm{H}_{2} \mathrm{O}$ & $\mathrm{CH}_{4}$ \\
\hline $1-4$ & 0.022 & $\sim 0$ & 0.006 & 0.000 & 0.972 \\
5 & 0.011 & $\sim 0$ & 0.003 & 0.490 & 0.496 \\
6 & 0.237 & 0.014 & 0.049 & 0.325 & 0.376 \\
$7-8$ & 0.183 & 0.041 & 0.203 & 0.560 & 0.013 \\
9 & 0.311 & 0.070 & 0.344 & 0.253 & 0.022 \\
10 & 0.416 & 0.093 & 0.460 & 0.002 & 0.029 \\
$12-16$ & 0.416 & 0.094 & 0.461 & 0 & 0.029 \\
$11,17-31$ & 0 & 0 & 0 & 1 & 0 \\
\hline
\end{tabular}


Table B.3: Molar composition of the flows on the air side for the G2P mode. Nodes refer to Figure B.1.

\begin{tabular}{rrr}
\hline Nodes & $\mathrm{O}_{2}$ & $\mathrm{~N}_{2}$ \\
\hline $32-34$ & 0.210 & 0.790 \\
$36-41$ & 0.050 & 0.950 \\
35 & 0.155 & 0.845 \\
\hline
\end{tabular}

Table B.4: Heat transferred in the different components in G2P mode. Components refer to Figure B.1. Component

Catalytic Recuperator Heat transferred [MW]

Cataly 
Highlights

- Electricity is stored as synthetic natural gas in the natural gas grid.

- Power-to-gas-to-power efficiency of $80 \%$ outperforms previous system designs.

- Methane is formed inside the solid oxide electrolysis cell at high pressure.

- An efficient link between electricity and natural gas markets is created. 